\title{
EXPANSÃO URBANA E FORMAÇÃO DE PERIFERIAS NAS CIDADES PEQUENAS DO PORTAL DO SERTÃO
}

\author{
Ythana de Oliveira Santos ${ }^{i}$ \\ Janio Santosii \\ Vinicus da Silva Machado Borges ${ }^{\mathrm{iii}}$
}

\begin{abstract}
Resumo: o artigo tem como objetivo analisar os fatores que influenciaram a expansão das pequenas cidades do Portal do Sertão, investigar as transformações nas estruturas urbanas e indicar os motivos que provocaram a formação de periferias em algumas delas. Para tanto, foram realizadas pesquisas bibliográficas, documentais e elaborados mapas temáticos. No Portal do Sertão, a expansão ocorreu face ações governamentais, pela luta por moradia e a oferta de residências por agentes imobiliários. Nem todas as cidades pequenas expandiram e formaram periferias. Onde o fenômeno é visível, se processa de diferentes formas e corrobora desigualdades, traduzidas em indicadores demográficos, de renda e inadequação de moradias. Por outro lado, envolve a leitura sobre escalas e dinâmicas nas quais cada cidade está inserida.

Palavras-chave: Expansão urbana; Portal do Sertão; Periferias; Pequenas cidades.
\end{abstract}

\section{URBAN EXPANSION AND FORMATION OF PERIPHERIES IN THE SMALL CITIES OF PORTAL DO SERTÃO}

\begin{abstract}
: this article analyzes the factors that influenced the expansion of the small towns of Portal do Sertão, investigate the transformations in the urban structures and indicates the reasons for the formation of peripheries in some. The methodology consisted of bibliographic and documentary research and elaboration of thematic maps. At Portal do Sertão, the expansion occurred due to government actions, the claim for housing and the offer of homes by real estate agents. However, there was no expansion and formation of peripheries in all the small towns. Where the phenomenon is visible, it takes place in different ways and corroborates inequalities, translated into demographic, income and precarious housing data. On the other hand, it involves reading about scales and the dynamics in which each city is inserted.
\end{abstract}

Keywords: urban expansion; Portal do Sertão; periphery, small town.

\footnotetext{
' Bolsista PIBIC/CNPq, Graduanda em Geografia/UEFS. E-mail: ythanaos@outlook.com.

ii Doutor em Geografia, Professor Pleno/DCHF/UEFS, http://orcid.org/0000-0003-0730-1271. E-mail: janiosantos@yahoo.com.br.

iiiGraduando em Geografia/UEFS. E-mail: viniciusborges 12@hotmail.com.
} 


\title{
EXPANSIÓN URBANA Y FORMACIÓN DE PERIFERIAS EN LAS PEQUEÑAS CIUDADES DE PORTAL DO SERTÃO
}

\begin{abstract}
Resumen: el artículo tiene como objetivo analizar los factores que influyeron en la expansión de las pequeñas ciudades de Portal do Sertão, investigar las transformaciones en las estructuras urbanas e indicar las razones que provocan la formación de periferias en algunas de ellas. La metodología consistió en la investigación bibliográfica y documental y la elaboración de mapas temáticos. En Portal do Sertão, la expansión se produjo debido a las acciones del gobierno, el reclamo de vivienda y la oferta de viviendas por parte de los agentes inmobiliarios. Sin embargo, no hubo expansión y formación de periferias en todas las ciudades pequeñas. Donde el fenómeno es visible, se presenta de diferentes formas y corrobora las desigualdades, traducidas en datos demográficos, de ingresos y de vivienda precaria. Por otro lado, implica leer sobre las escalas y el nivel socioeconómico en el que se inserta cada ciudad.

Palabras-clave: Expansión urbana; Portal do Sertão; Periferia, Pequeña ciudad
\end{abstract}

\section{Introdução}

Nas quatro últimas décadas, são observadas profundas transformações nas cidades pequenas, como consequência de alterações que se desdobraram em várias escalas, que expressam, por exemplo, aumento de sua população urbana. Isso é resultado de novas relações de trabalho e de produção que foram engendradas durante todo o século XX, até porque novos aspectos da vida e dinâmica das cidades passaram a fortalecer tal lógica.

Com base nesses argumentos, desenvolve-se este texto com vistas a pensar, com base Território de Identidade Portal do Sertão, qual o grau de expansão das pequenas cidades e investigar os fatores que influenciaram a formação de periferias nessas áreas.

No que concerne à expansão urbana, entre 1940 e 2000, SANTOS (2019) reforça e ideia que parte desses núcleos pequenos cresceu territorialmente. Entretanto, não é o crescimento do tecido urbano em si que decorre na periferização, fenômeno que se acentua em tais cidades, mas a ação e os interesses dos agentes que as produzem.

Para tanto, foram realizadas pesquisas bibliográficas sobre expansão urbana, cidades pequenas e periferia. Também houve o levantamento de dados acerca das marcas 
históricas e da dinâmica populacional e socioeconômica do Portal do Sertão. No QGis, elaborou-se mapas temáticos para: [1] Avaliar a expansão urbana, entre 1984 e 2019, com base em imagens de satélites do Instituto Nacional de Pesquisas Espaciais (INPE); [2] Verificar os casos em que foram constituídas periferias; e [3] Compor um panorama da dinâmica dessas pequenas cidades.

O artigo está organizado em três partes: na primeira, discute-se cidades pequenas, expansão urbana e periferias do ponto de vista teórico; na segunda, caracteriza-se o Território de Identidade Portal do Sertão, com seus aspectos históricos e econômicos; e, por último, avalia-se a expansão nas cidades pequenas, assim como suas características e as periferias constituídas.

\section{Cidades pequenas, expansão urbana e periferias: breves considerações}

Segundo SANTOS (2005), as mudanças nas cidades pequenas são resultado dos novos modelos de produção e consumo, perfil que se repete de forma geral nos países subdesenvolvidos. Apenas recentemente tais cidades se alastraram no território nacional e isso foi causado pela modernização da tecnologia, independente da industrialização. Ocorreu primeiramente com o aparelhamento estatal e ocasionou também a melhoria de seus serviços. Em consequência disso, as exigências da população das pequenas cidades também aumentaram, com foco em serviços de maior qualidade, principalmente educação e saúde, o que criou condições para melhorar, relativamente, sua infraestrutura urbana. Contudo, as pequenas cidades ainda sofrem com problemas relacionados à falta de serviços básicos para grande parcela da população. Por isso, para serem supridos, deslocam-se para outras localidades onde há maior especialidade.

As mudanças que ocorreram nesses espaços passaram a ser percebidas e chamaram a atenção de alguns pesquisadores, como SANTOS (2019) e CORRÊA (2011). A problemática sobre sua definição ganhou evidência e trouxe ao debate o conceito de "cidade pequena". Diferente de como são pensadas, elas não apresentam 
homogeneidade interna, menos ainda nas suas relações, e não permitem a construção de um conceito abrangente que corresponda integralmente as suas formas e dinâmicas. MAIA (2009) questiona se os estudos acerca das metrópoles cabem para as cidades pequenas ou para as cidades não-metropolitanas. Fora por interesses estatísticos de alguns órgãos, parâmetros demográficos máximos ou mínimos servem muito mais para dizer o que não é uma pequena cidade do que para conceituá-la. Diante disso, concluise que definir a cidade apenas como pequena por critérios demográficos é insuficiente, porque inviabiliza perceber as características únicas de cada uma delas.

A escolha por trabalhar com essa temática e suas transformações confirma a preocupação em verificar como os pequenos municípios recebem os impactos das modificações pelas quais a sociedade passa. Para que isso seja atingido é indispensável a compreensão das interações que as influenciam em diferentes escalas.

O importante na discussão sobre as pequenas cidades é observar sua realidade, para que se possa compreender a problemática que envolve o tema (necessidades, potencialidades, interações com o entorno e as áreas distantes). Por outro lado, criar um arcabouço teórico e metodológico confiável e, ao partir desse, estudos que possam ser feitos para que tais áreas urbanas sejam debatidas, com o intuito de compreender os traços e as potencialidades deixem de ser ignoradas e passem a ser devidamente avaliadas.

Para SANTOS (2019), de certa forma, podem ser sistematizados em cinco os aspectos que, em geral, os autores atinam-se ao tratar do tema cidades pequenas: escala, grau de modernidade, vida cotidiana, questão demográfica e dinâmica urbana.

Segundo Corrêa, a cidade pequena é:

[...]um núcleo dotado da função de sede municipal. [...] Ser sede municipal significa certo poder de gestão de um dado território, o município, para o qual a presença de instituições e serviços públicos, além do acesso a tributos estaduais e federais tornam-se essenciais. Associada a essa função político-administrativa, seja de forma causal ou em conseqüência, há atividades econômicas vinculadas à produção e circulação de mercadorias e à prestação de serviços (CORREA, 2011: $6)$. 
Com base no fragmento acima, é possível reiterar a ideia de que a pequena cidade deixou de ser algo voltado apenas para o âmbito rural e passou a ter aspectos mais urbanos, sobremodo ao fortalecer a função administrativa. Mesmo assim, várias cidades ainda mantêm atividades inexpressivas para suprir suas necessidades locais, sobretudo de caráter produtivo, e ficam dependentes de fundos de recursos públicos.

A análise do espaço urbano parte do pressuposto de que esse é o lugar onde se desenvolve e significa a vida cotidiana, através de agentes e sujeitos concretos. Esses atuam para sua organização e agem conforme a dinâmica capitalista, que, ao longo do tempo, demandou diferentes necessidades de relações de produção e, como consequência, da luta social (CORRÊA, 1989). Ele está em constante reorganização, que se vincula às ações realizadas pelos agentes e pelos sujeitos. Entretanto, o espaço urbano continua fragmentado, articulado e, ao mesmo tempo, refletor e condicionante de uma sociedade desigual, mesmo reinventando-se em suas formas e funções. Logo, pode-se considerar o equilíbrio social como um discurso ideológico, já que esse espaço não permite sua concretização.

Os agentes concretos que produzem o espaço urbano são: proprietários dos meios de produção, proprietários fundiários, promotores imobiliários, Estado (em suas três instâncias) e, por fim, grupos excluídos (CORRÊA, 1989). A nosso ver, esses últimos são, na verdade, as classes sociais segregadas.

O Estado possui papel fundamental na caracterização do uso do solo urbano, pois sistematiza e regulamenta sua utilização. Porém, são os agentes do capital que atuam no condicionamento concreto das práticas socioespaciais e, como consequência, promovem a fragmentação e segregação espacial, e causam conflitos. É nesse cenário, repleto de agentes com interesses conflitantes e objetivos distintos, que o espaço urbano é "organizado e reorganizado" para atender diferentes demandas, as quais produzem o que conhecemos como a cidade moderna (CARLOS, 2007).

O espaço urbano é o lugar que propicia a ação humana, mas também é produto dela, o que ocasiona diferentes significações que Ihe são atribuídas. Por ser não reprodutiva, bastante monopolizada e insubstituível para a produção capitalista, a terra assume um 
preço. O mercado e o uso do solo urbano estão vinculados, pois o preço do terreno é o meio de acesso à utilização do espaço, sendo esse vendido ou alugado (SINGER, 1982). A terra tem valorização diferencial quanto à qualidade de localização, pois leva-se em consideração aspectos físicos e locacionais para atribuir a valoração de determinada área.

A necessidade cada vez maior por terreno, produto da aglomeração reproduzida no espaço urbano, através das atividades econômicas que são intensificadas pela concentração do capital e pela dinâmica de acumulação capitalista, influencia diretamente na urbanização (SILVA, 1995). Dois fatores importantes para garantir o modo diferenciado como o processo ocorre estão relacionados à disponibilidade econômica da sociedade, pois o preço vincula-se com o que a demanda está disposta a pagar, e as características físicas. Aliás, "barreiras ambientais" são fundamentais para definir investimentos em determinada área, e não é lucrativo para o capital sancionálas.

O principal mecanismo de expansão da cidade contemporânea é a integração do espaço rural ao urbano, que, como explicitado, é viabilizado pela regulamentação do Estado e tem como principais beneficiários os proprietários fundiários e os incorporadores imobiliários, elucidado na afirmativa de que:

O planeamento urbano constitui a expressão mais acabada de controle administrativo sobre a organização da cidade. Trata-se de delegar no Estado a gestão da expansão urbana, a construção das infraestruturas e a decisão sobre a localização das atividades na cidade. (SILVA, 1995: 123)

SINGER (1982: 29) explica a expansão nas cidades ao apontar que "O crescimento do solo urbano implica necessariamente na reestruturação do uso das áreas já ocupadas". A estrutura se modifica ao longo do tempo ou pelo tamanho da cidade, que era caracterizada pelas áreas residenciais de alto nível localizadas no centro, e isso se modificou. A expansão do centro, que passa a se aproximar dessas áreas, provoca maior movimentação e violência, o que, junto aos interesses dos agentes imobiliários, levou novos moradores a residir em locais mais distantes. O deslocamento das camadas com 
maior renda para a periferia não mais absorve o sentido de pobreza, já que são áreas captadas pela promoção imobiliária de alto nível (SINGER, 1982).

Com a expansão urbana, surgem novas formas de segregação. A produção espacial revela as desigualdades do processo e os lugares são restringidos pelos limites impostos pela propriedade privada (CARLOS, 2007). Terrenos com potencial residencial não são convertidos em moradia e, em maioria, são temporariamente "abandonados"; mas o capital imobiliário também não permite sua ocupação: “A propriedade privada do solo urbano faz com que a posse de uma renda monetária seja requisito indispensável à ocupação do solo urbano" (SINGER, 1982: 33). Como os "grupos excluídos" também não têm direito ao centro, são realocados para as periferias. Essas, aplicadas no sentido de pobreza, não possuem infraestrutura urbana ou serviços públicos e explicitam a organização capitalista do solo. O uso, mais uma vez, depende dos objetivos de seus proprietários e da ação do Estado, através da legislação.

A realização da vida e da identidade através do tempo é caracterizada pelo uso do espaço e pela regulamentação, que é feita pelo Estado em suas três esferas. Entretanto, esse uso é uma ação socioespacial concreta e, assim, coagido por agentes hegemônicos promove contradições e, consequentemente, conflitos entre as classes. A contradição mais explicita no espaço urbano atual, a estratificação social, é representada pela segregação das áreas residenciais.

No auge do planejamento urbano brasileiro, nos anos de 1970 e 1980, as cidades cresceram quase sem legislação, e as periferias se estenderam, assim como a falta de infraestrutura urbana. O planejamento se revelava preocupado com a promoção do setor imobiliário: a conversão de solo rural em urbano, valorização dos imóveis, atividades especulativas e a construção em massa de habitações populares (MARICATO, 2002). Entretanto, não houve falta de planos diretores municipais. A própria Constituição de 1988 comprova a obrigatoriedade desses planos em cidades com mais de 20 mil habitantes. Portanto, é na falta de coesão entre a teoria e a execução que está o maior problema. 
As velhas e novas formas de ação no espaço urbano são comprovadas, mais uma vez, no que refere a urbanização nas cidades brasileiras, vinculada tanto ao sistema colonial, coronelista e patrimonial, quanto ao regime republicano do século XX, que é neoliberal e especulativo (MARICATO, 2002). No entanto, ambos sistemas formaram gestões urbanas de baixo orçamento social e serviços urbanos, voltadas à especulação imobiliária ao invés de não segregacionistas. Como se pode notar através dos financiamentos realizados pelo Sistema Financeiro de Habitação (SFH) e o Banco Nacional de Habitação (BNH), criados para promoção de moradias aos grupos sociais pobres, como forma de reparação do caos urbano, mas financiaram o aumento da segregação. Por outro lado, garantiram infraestrutura para bairros de classes médias e altas, em decorrência dos interesses do setor imobiliário, como vias de acesso aos "novos centros" de várias cidades, a partir de 1970, que beneficiaram a promoção imobiliária de alto nível.

Dessa forma, a legislação é utilizada de duas maneiras: na ação ambígua ou por aplicação arbitrária (MARICATO, 2002). É implícito que as contradições do espaço urbano, quando insuportáveis, desencadeariam uma guerra civil, pelos conflitos insustentáveis. Por isso, o Estado, que age em favor da capital, mas apazigua as contradições, tolera a ocupação em áreas de pouco interesse e intervém nas ocupações que apresentam benéficos locacionais.

O conceito de periferia, por muito tempo, foi abordado através da ótica geométrica, sendo caracterizado como uma área do tecido urbano distante do centro e, portanto, como espaço pouco infraestruturado. Diante disso, difundiu-se no senso comum e na academia a ideia do termo relativa exclusivamente à pobreza. Entretanto, a periferia passou por várias redefinições no âmbito do processo de ocupação e, consequentemente, novas elaborações teóricas transformaram as formas de abordagem sobre o tema.

Segundo CHAVEIRO (2007), para a redefinição da periferia urbana é necessário atentarse para dois fatores: as peculiaridades históricas e o tipo de segregação dominante, pois 
toda estrutura é construída através de um processo e a cidade reflete concretamente as desigualdades sociais.

Assim, pode-se conceituar a periferização como "a acumulação desigual de capital, refletida nas condições de moradia" (MOURA, SOARES, 2009: 23). O mesmo autor também a define pelos pontos de vista social e urbanístico. No primeiro, infere-se que essa parcela do solo urbano, geralmente, com infraestrutura inadequada, é destinada à população menos abastada; enquanto a ótica urbanística pressupõe que a periferia é marcada pela baixa densidade de ocupação e rápida expansão para áreas mais afastadas, o que fragmenta o espaço urbano (MOURA, SOARES, 2009).

Nessa direção, pensar o subúrbio é pensar a fragmentação do espaço urbano, seja ela espontânea ou regulada. Os produtos da autossegregação são os condomínios fechados promovidos pelo setor imobiliário privado, além da alta infraestrutura e serviços, enquanto a fragmentação regulada ou a periferia planificada é promovida pelo Estado e, na maioria das vezes, destinada as classes com menor poder aquisitivo. Essas maneiras de fragmentação podem ser ainda analisadas por dois fenômenos: a promoção imobiliária e a segregação socioespacial, que coexistem no espaço urbano e são ambas produto da expansão e divisão do espaço, além de refletirem a dualidade do conceito de periferia. Isso permite constatar que a área periférica tem seu valor pautado na localização distante do centro, mas necessita da mobilidade, infraestrutura e das condições ambientais para definir seus moradores.

A análise da cidade na qual se dá essa ordem também é essencial para definir o tipo de periferia que irá se consolidar. A lógica que materializa as cidades diverge de acordo com seu tamanho, grau de influência e os objetivos da expansão e, dessa forma, cada cidade possui características próprias. Assim, algumas cidades pequenas possuem periferias difíceis de distinguir, como veremos posteriormente.

Com a Primeira Revolução Industrial e o rápido crescimento urbano, surgiram os primeiros subúrbios, o que transformou estruturalmente as cidades. No século XIX, o aumento populacional, paralelo à decadência das áreas rurais, contribuiu para a expansão urbana acelerada e desigual. Assim, a relação centro-periferia era pensada 
separadamente; os trabalhadores ocupavam os centros por causa da proximidade com o trabalho e os "burgueses" buscavam o isolamento do caos urbano (SPOSITO, 2004). No Brasil, a expansão dos centros urbanos e, consequentemente, da periferização aconteceu, mais evidentemente, a partir de 1960. O país seguiu o modelo europeu e a crescente violência fez com que as classes com maior poder aquisitivo se autossegregassem em áreas distantes. Entretanto, esse fenômeno ocorreu nas cidades grandes e médias, com centros e áreas periféricas bem definidas. Na década de 1970, por outro lado, a expansão começou a ocorrer devido a ocupações dos vazios urbanos pelos trabalhadores, o que ocasionou a criação dos programas governamentais de planeamento para conter o avanço da ocupação descontrolada nas cidades (CHAVEIRO, 2007).

Portanto, a formação das periferias não é algo homogêneo. Segundo SPOSITO (2004: 120), "o tamanho da cidade determina a distância, a extensão e a homogeneidade da periferia" e cada uma possui suas particularidades, tanto no processo urbanização, quanto nas características internas. Assim, a meta é apresentar contribuições necessárias referentes à periferização das cidades pequenas, que, em sua maioria, não receberam grandes polos industriais, nem possuem uma classe média numerosa, num primeiro momento, mas que formaram periferias com certa particularidade.

\section{As pequenas cidades do Portal do Sertão}

Nas últimas décadas, ocorreram mudanças nas cidades pequenas, tanto no contingente populacional, quanto nas atividades econômicas, sociais e políticas. Algumas passaram a desempenhar maiores papeis econômicos e apresentam novas funções políticoadministrativas, tendo ampliado o poder de gestão do território.

O processo de globalização foi um dos grandes influenciadores para as mudanças que ocorreram nos pequenos municípios em consequência da presença de atividades voltadas à produção e circulação de mercadorias. SANTOS (2019: 44) aponta que “[...] cada centro, por menor que seja, sofreu o impacto dessas mudanças globais, e participa 
de uma maneira ou de outra, desse processo". Portanto, os pequenos municípios deixaram de ser locais voltados exclusivamente para o âmbito rural, conforme ressalta CORRÊA (2011).

A posteriori, o processo citado também influenciou a lógica das pequenas cidades e promoveu o desprendimento geográfico da produção, o que possibilitou a implementação de indústrias e sérvios no cotidiano de algumas pequenas cidades. Isso foi motivado não só pela globalização, mas também por outras causas e, nessas cidades, alterou certos limites que antes eram essenciais para presença de algumas atividades: aumento populacional, nível de renda, nível de consumo, etc. Para que houvesse tal fato, exigiu-se que certas pequenas cidades fossem modificadas e se tornassem mais "atrativas" para as indústrias, o capital agrário, o terciário, etc.; ou seja, mudaram, mas para atender novos interesses da reprodução capitalista.

O Território de Identidade Portal do Sertão, regionalização proposta pelo governo do Estado da Bahia, é parte do Polígono das Secas e composto por dezessete municípios (Mapa 1). Em sua maioria, são pequenos e têm como base econômica o setor primário. Feira de Santana, cidade polo, apresenta maior expressão, sobretudo no terciário e no secundário. Três importantes rodovias federais, a BR-101, a BR-116 e a BR-324, e cinco estaduais, tais como a BA-504, BA-411, BA-120, BA-515 e BA-084, constituem os eixos de articulação entre o espaço regional e outras áreas da Bahia e do Brasil.

As pequenas cidades estudadas não se constituíram igualmente, entretanto apresentam tendências comuns em suas origens. As mudanças político-administrativas que ocorreram a partir de 1940 modificaram a lógica das áreas urbanas e influenciaram diretamente na definição das 17 cidades do Portal do Sertão, das quais 16 são analisadas.

Mapa 1: Território de Identidade Portal do Sertão, Bahia, 2020 

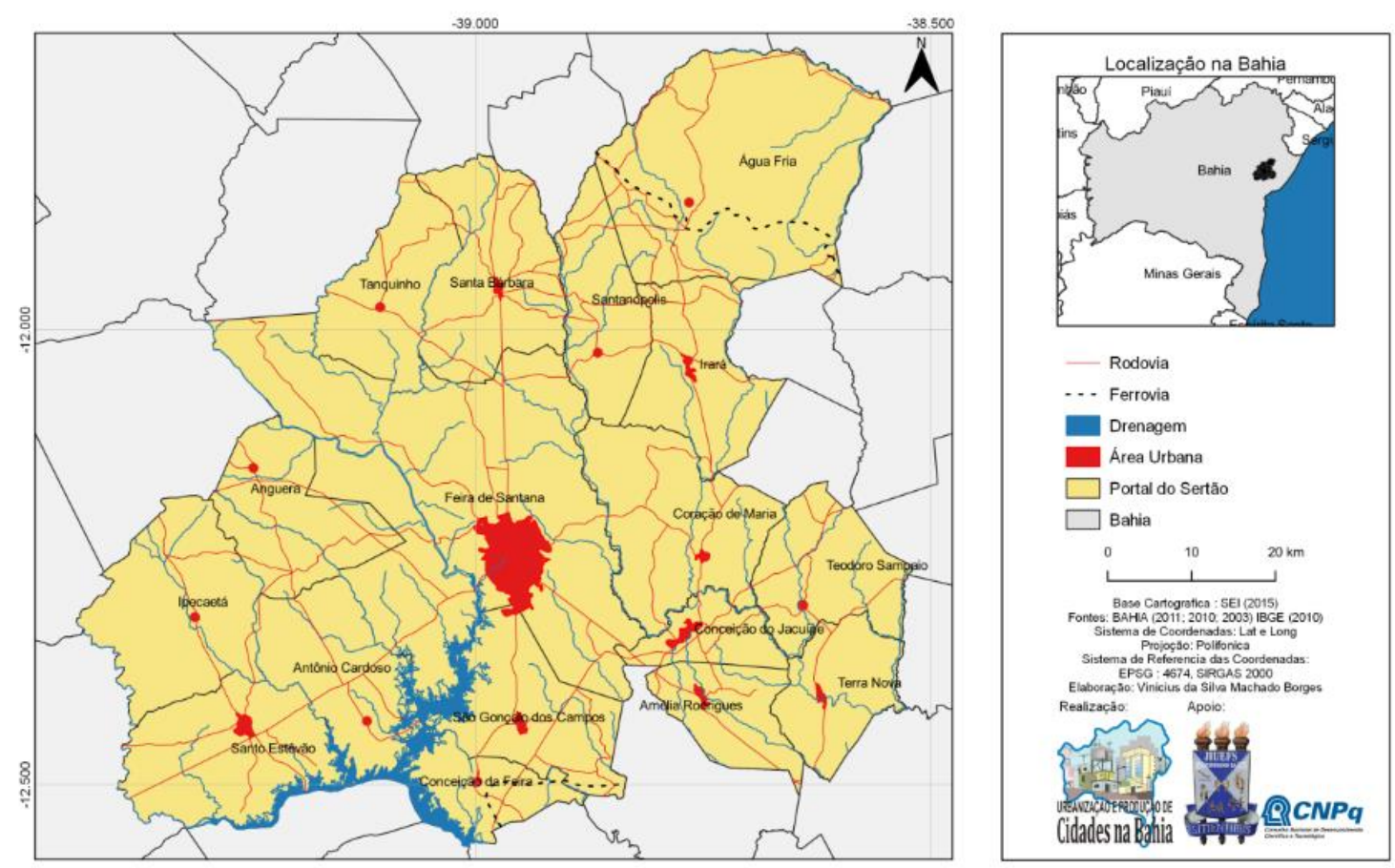

A partir de 1960 e 1970, o êxodo rural e os novos modelos de produção e consumo, baseados na lógica desenvolvimentista, ocasionaram a aceleração do processo de urbanização no Portal da Sertão. Outro fato refere-se à implantação do Centro Industrial Subaé (CIS), que embora tenha sido consolidado na cidade de Feira de Santana, trouxe nova dinâmica para a atividade industrial na região. Também, a ampliação dos setores públicos afetou significativamente essas cidades (SANTOS, 2020). A partir desse período, os municípios apresentaram déficits crescentes na população rural e aumentaram de modo significativo a urbana.

Em 2010, a diferença entre a população de Feira de Santana, com 510.635 habitantes, e os demais municípios que compõem a região é notável. Apenas mais sete possuíam população total superior a 20 mil habitantes, que conformavam 30,31\% do Portal do Sertão. Nove municípios possuíam menos de 20 mil habitantes e oito tinham taxas de urbanização que ultrapassavam 50\% (Tabela 1).

Tabela 1: População Total, Urbana e Rural das cidades e Taxa de urbanização do Território de identidade do Portal do Sertão, Bahia, 2010.

\begin{tabular}{|c|c|c|c|c|}
\hline Municípios: & Urbana & Rural & Total & $\begin{array}{c}\text { Taxa de } \\
\text { Urbanização }\end{array}$ \\
\hline
\end{tabular}




\begin{tabular}{|c|c|c|c|c|}
\hline Água Fria & 5.777 & 9.954 & 15.731 & 36,72 \\
\hline Amélia Rodrigues & 19.957 & 5.233 & 25.190 & 79,22 \\
\hline Anguera & 4.326 & 5.916 & 10.242 & 42,23 \\
\hline Antônio Cardoso & 3.225 & 8.329 & 11.554 & 27,91 \\
\hline Conceição da Feira & 13.137 & 7.254 & 20.391 & 64,42 \\
\hline Conceição do Jacuípe & 23.539 & 6.584 & 30.123 & 78,14 \\
\hline Coração de Maria & 9.400 & 13.001 & 22.401 & 41,96 \\
\hline Feira de Santana & 510.635 & 46.007 & 556.642 & 91,73 \\
\hline Ipecaetá & 2.637 & 12.694 & 15.331 & 17,20 \\
\hline Irará & 11.246 & 16.220 & 27.466 & 40,93 \\
\hline Santa Bárbara & 8.669 & 10.395 & 19.064 & 45,47 \\
\hline Santanópolis & 1.684 & 7.092 & 8.776 & 19,18 \\
\hline Santo Estêvão & 27.690 & 20.190 & 47.880 & 57,83 \\
\hline São Gonçalo dos Campos & 16.505 & 16.778 & 33.283 & 49,58 \\
\hline Tanquinho & 5.711 & 2.297 & 8.008 & 71,31 \\
\hline Teodoro Sampaio & 6.341 & 1.554 & 7.895 & 80,31 \\
\hline Terra Nova & 11.488 & 1.315 & 12.803 & 89,72 \\
\hline Total & $\mathbf{6 8 1 . 9 6 7}$ & $\mathbf{1 9 0 . 8 1 3}$ & $\mathbf{8 7 2 . 7 8 0}$ & $\mathbf{7 8 , 1 4}$ \\
\hline Fonte: IBGE (2010) & & & & \\
\hline
\end{tabular}

Os setores que influenciam o PIB nos pequenos municípios do Portal do Sertão modificaram-se no decorrer dos anos. Até 1985, o principal ainda era o primário, o espaço rural era aquele que tinha a maior importância econômica e partia dele grande parcela da produção regional. Todavia, em 2017, o setor terciário tornou-se maior parte da composição do PIB e em 15 dos 16 pequenos municípios ele era a maior fonte da produção (IBGE, 2019).

Entretanto, as taxas das ocupações dos municípios pequenos (Mapa 2) mostram que, no ano de 2010, o setor primário era, para a maioria, a principal fonte de emprego, seguido pelo terciário. Em 2010, o foco principal do trabalho nos pequenos municípios mantinha-se no primário, pois, dos 16,8 vinculavam-se a esse setor, ainda que 0 terciário exercesse maior participação em 8 casos (IBGE, 2000, 2010). Assim, mesmo com as ocupações primárias a diminuírem a participação ao longo da década, ainda têm relevância expressiva em relação ao emprego no Portal do Sertão. Por isso, o PIB não 
deve ser considerado como indicador absoluto para determinar a economia dos municípios, sobretudo os pequenos.

\section{Mapa 2: Percentual da população ocupada setor primário,} Portal do Sertão, Bahia, 2010
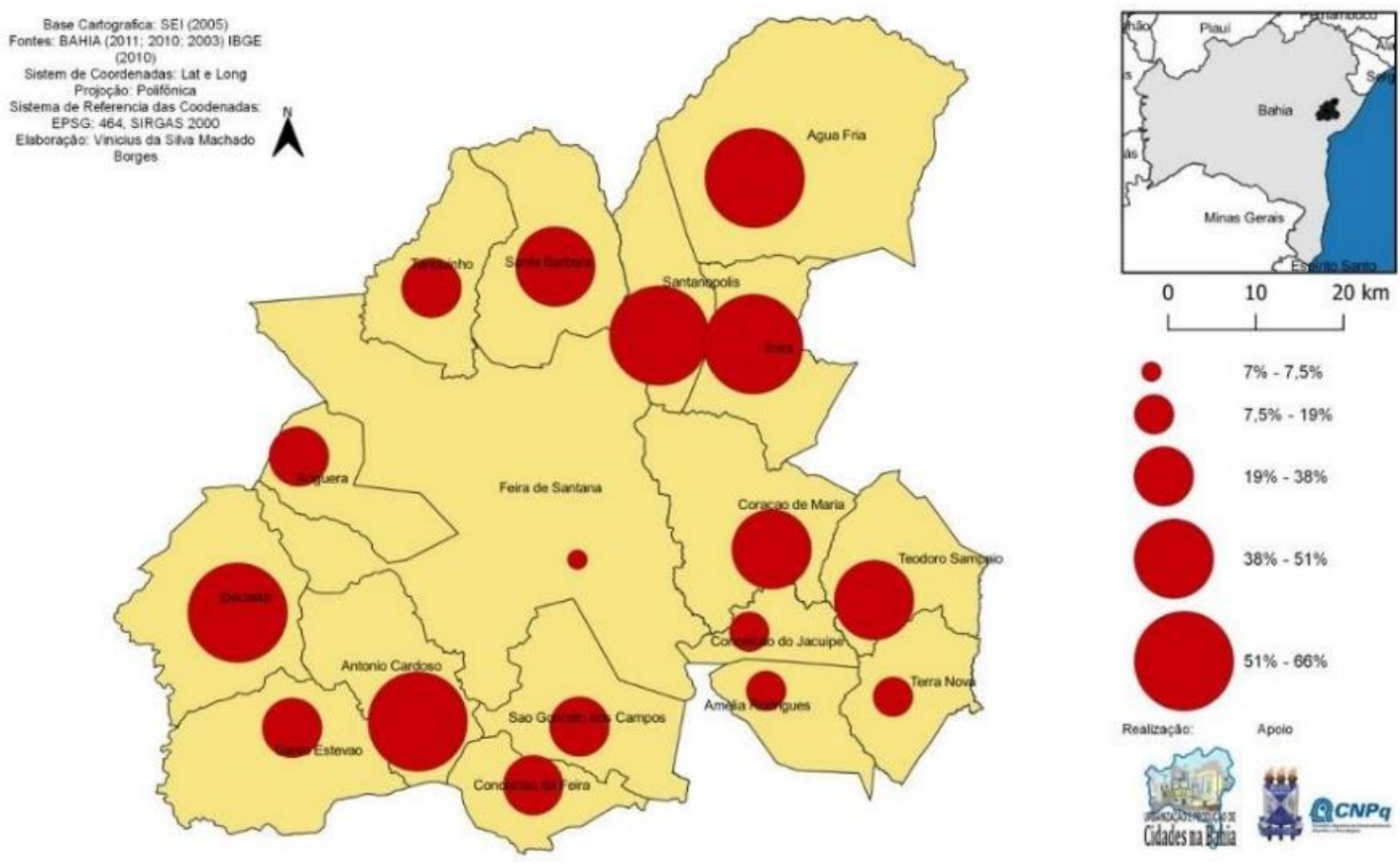

Embora o PIB terciário se destaque nas cidades pequenas, suas atividades estão muito vinculadas ao setor público. SANTOS (2020) denomina isso como pseudo-terceirização, pois o comércio e os serviços apresentados nos índices são dependentes dos recursos da administração pública e, por isso, não são tão dinâmicos. As que apresentaram maior dinamismo nas atividades secundárias e terciárias foram São Gonçalo dos Campos, Santo Estevão e Conceição do Jacuípe, mas o setor primário tem destaque em boa parte do Portal do Sertão.

\section{Periferias e seus diferentes padrões nas cidades pequenas do Portal do Sertão}


O melhoramento de rodovias federais e estaduais, a exemplo da BR-116 e BR-101, incitou a formação de aglomerados que se consolidaram e expandiram em seu entorno, o que foi um impulso para urbanização.

No período de 1984 a 2019, as cidades que mais se destacaram em relação à expansão foram Santo Estevão, Conceição do Jacuípe, Amélia Rodrigues e São Gonçalo dos Campos, conforme mapas 3, 4, 5, 6 e 7. Essas cidades apresentam certa proximidade com Feira de Santana, a maior do Território de Identidade, e, consequentemente, exerce influência na expansão, apesar de não ser regra. Merecem destaques São Gonçalo dos Campos e Conceição do Jacuípe, que, devido à dinâmicas urbanas consolidadas e ao aumento territorial, expressam possibilidades de conurbação com Feira de Santana no futuro. Por outo lado, em cidades como Anguera, Santanópolis e Ipecaetá o processo é incipiente.

A tendência ao crescimento territorial foi incentivada por modificações no consumo, produção e nas relações de trabalho. Num primeiro momento, a expansão advém da expropriação rural e da necessidade de terreno face a intensificação de atividades econômicas, algumas ligadas ao setor primário, e, mais recentemente, pela conversão do solo rural em urbano. Entretanto, a busca por acesso a serviços, como saúde e educação, a ação dos agentes fundiários e imobiliários e os impulsos do governo através de residências ofertadas por programas habitacionais, sobretudo a partir de 2009, com o Programa Minha Casa Minha Vida, também alteraram as estruturas urbanas (SANTOS, 2020).

\section{Mapa 3: Expansão das cidades de Santa Bárbara, Água Fria, Santanópolis e Irará, 1984 a 2019}




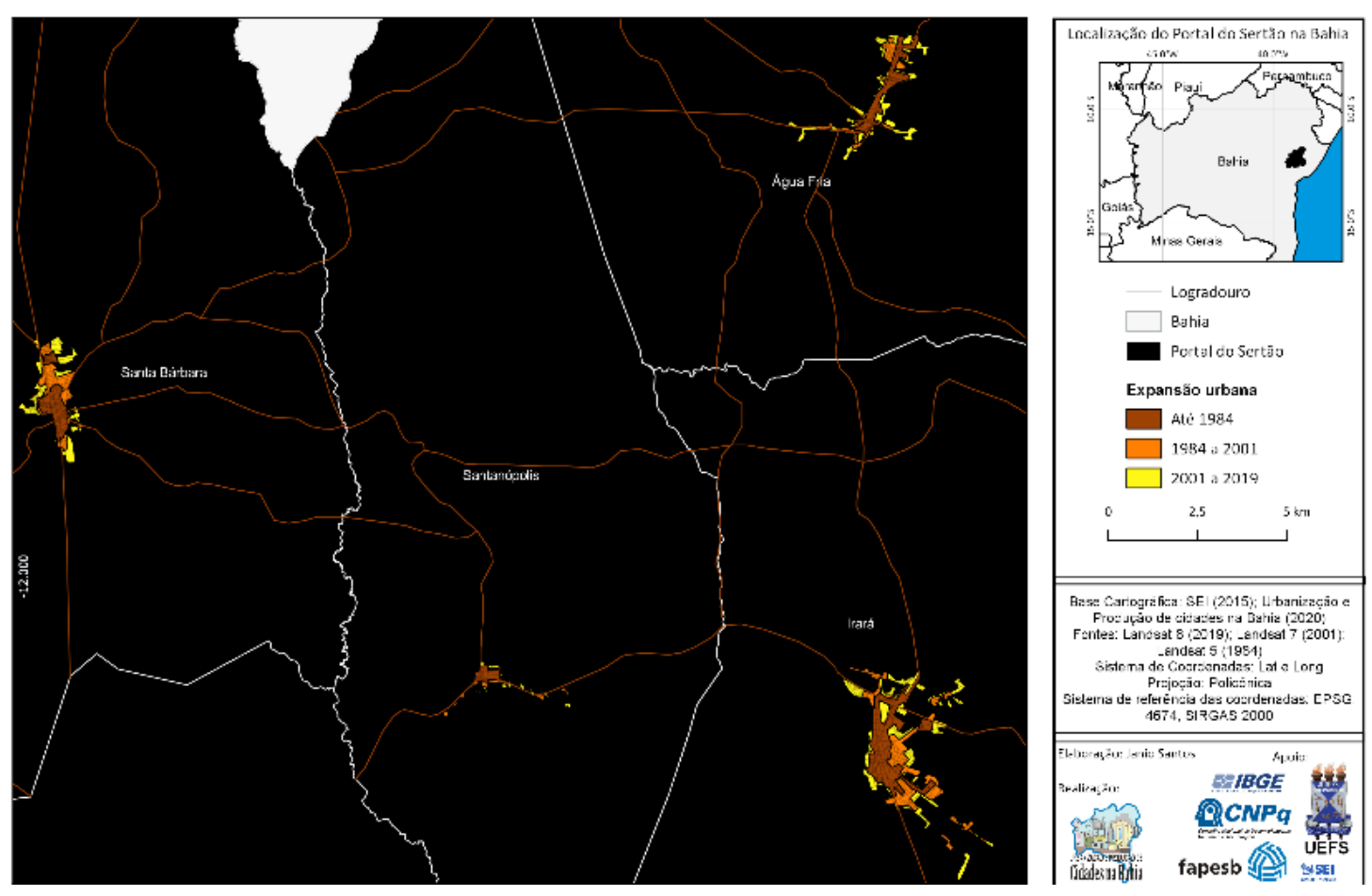


Mapa 4: Expansão das cidades de Coração de Maria, Conceição do Jacuípe, Teodoro Sampaio, Terra Nova e Amélia Rodrigues, 1984 a 2019
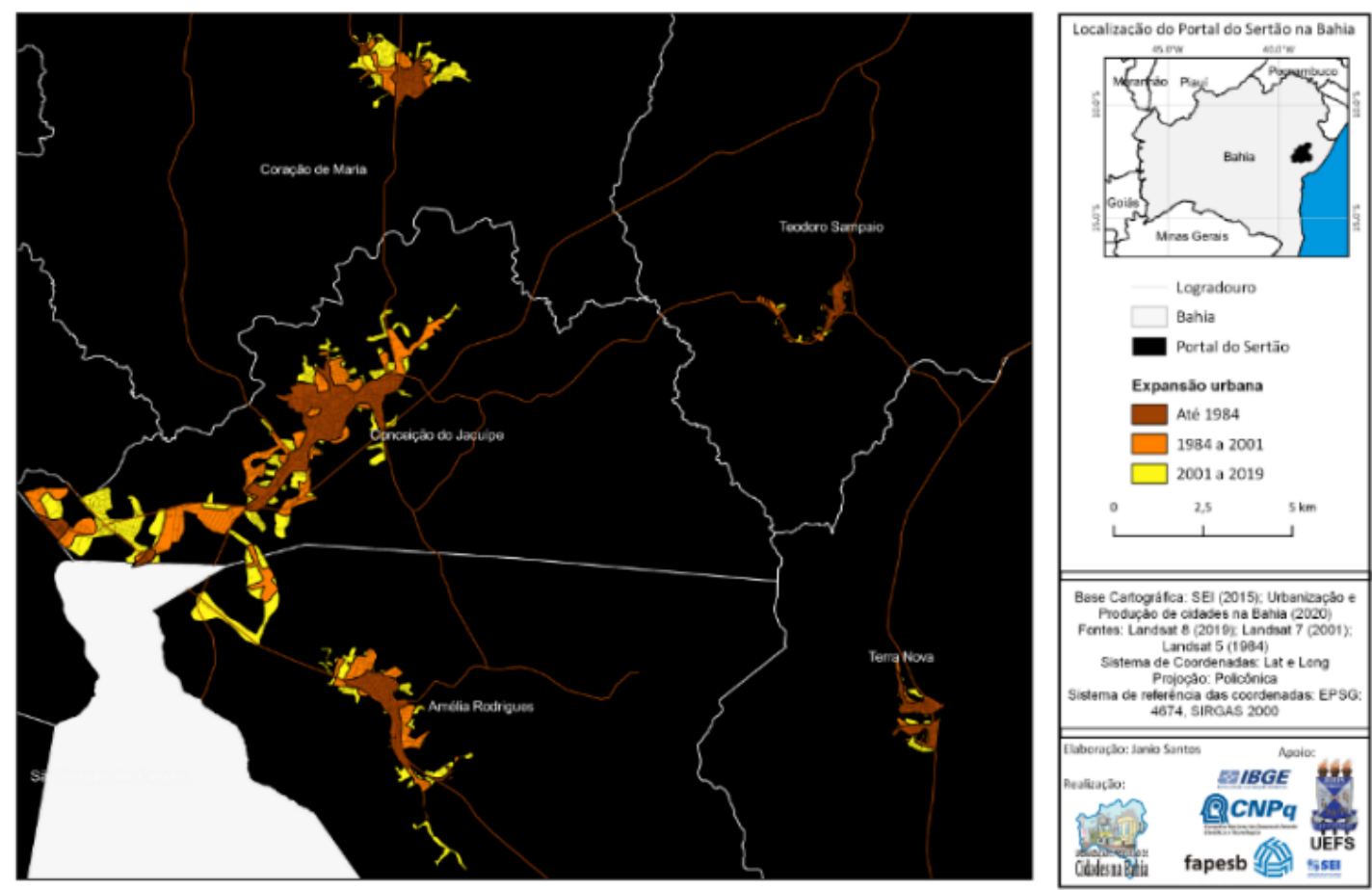

Mapa 5: Expansão das cidades de Antônio Cardoso, São Gonçalo dos Campos e Conceição da Feira, 1984 a 2019 

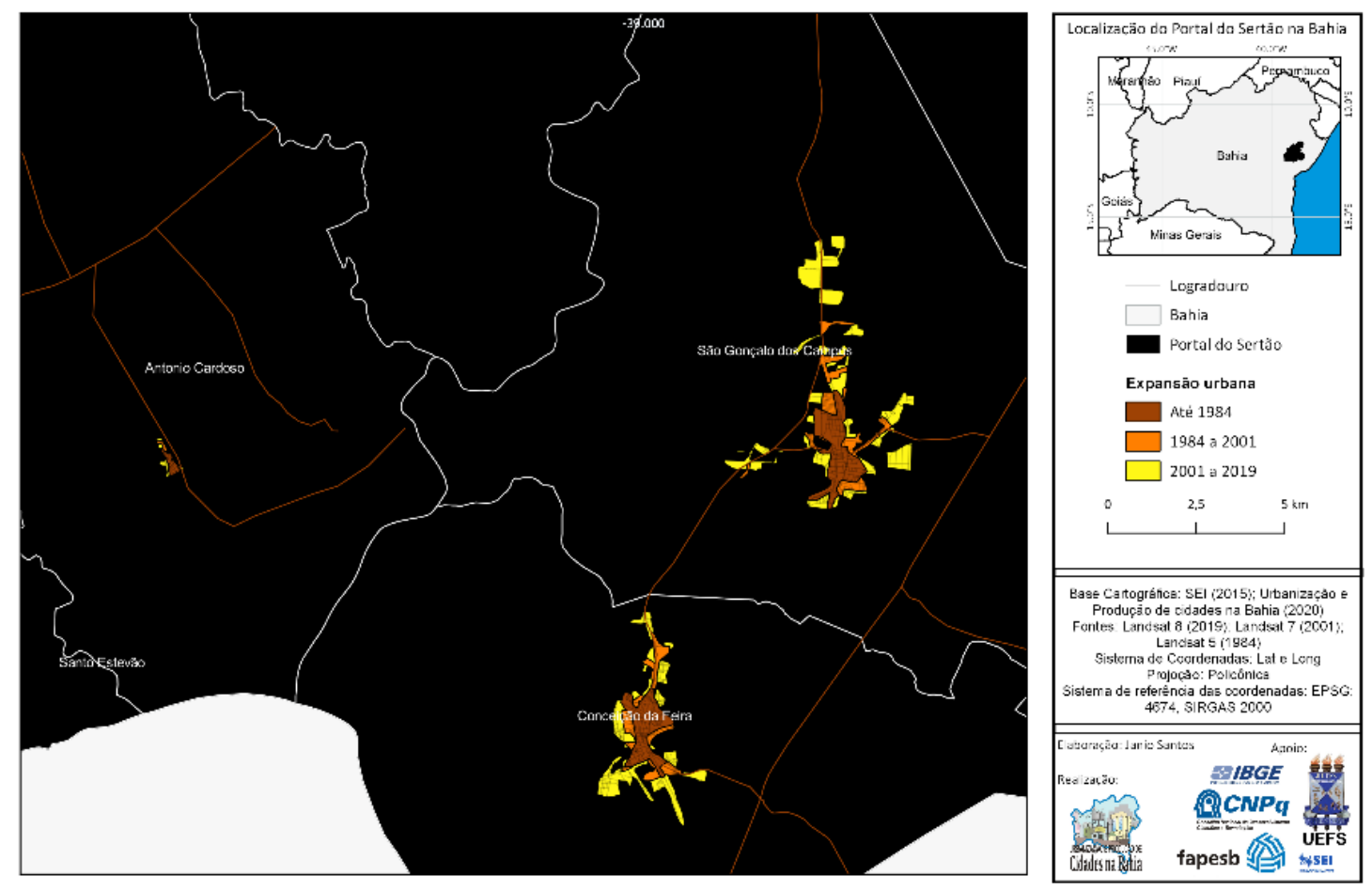

Mapa 6: Expansão das cidades de Ipacaetá e Santo Estevão, 1984 a 2019
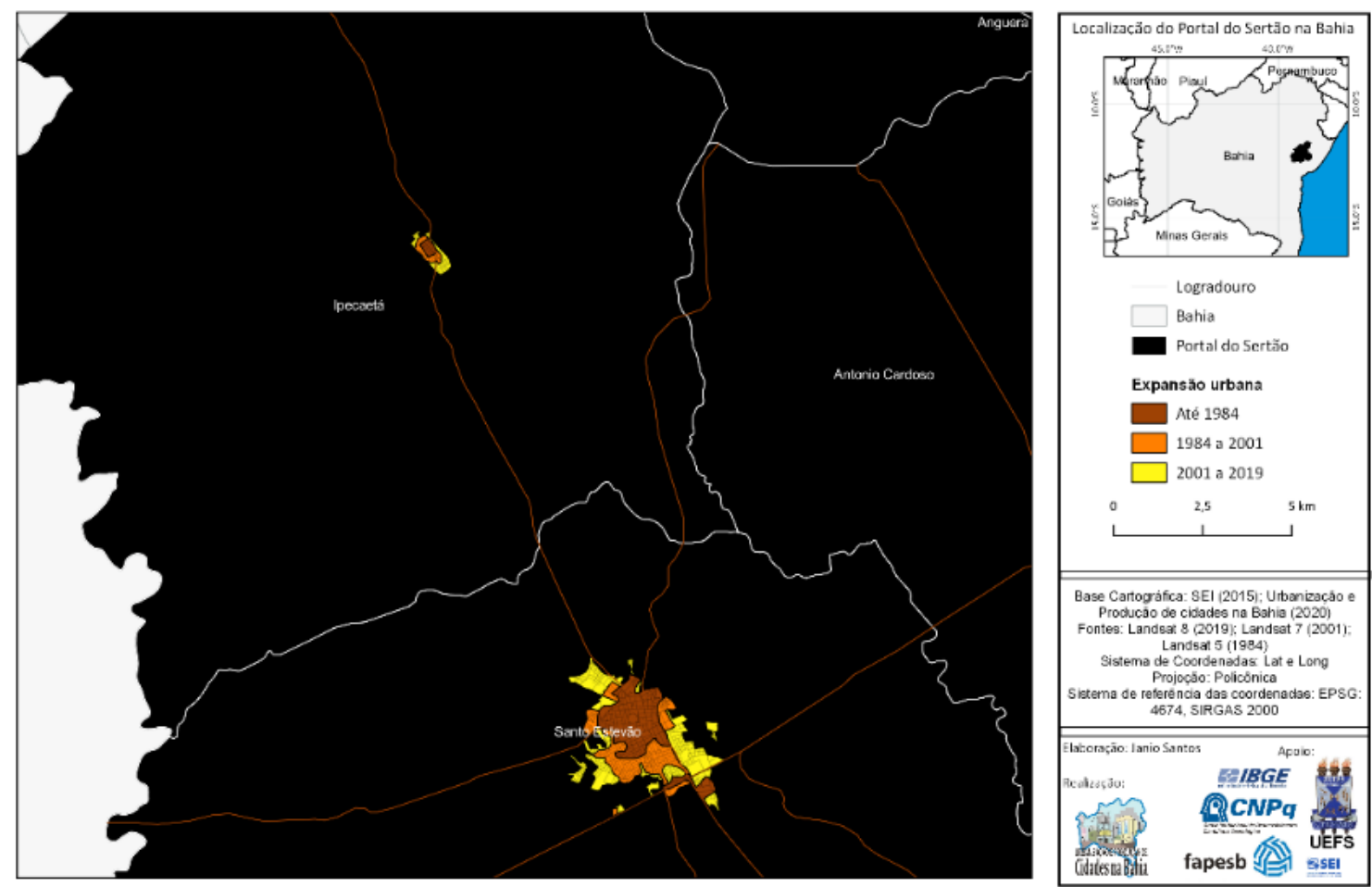

Oliveira Santos; Santos; Borges, Expansão urbana e formação de periferias nas cidades pequenas do Portal do Sertão DOI: https://doi.org/10.51308/continentes.v1i18.300 
Mapa 7 Expansão das cidades de Tanquinho e Anguera, 1984 a 2019

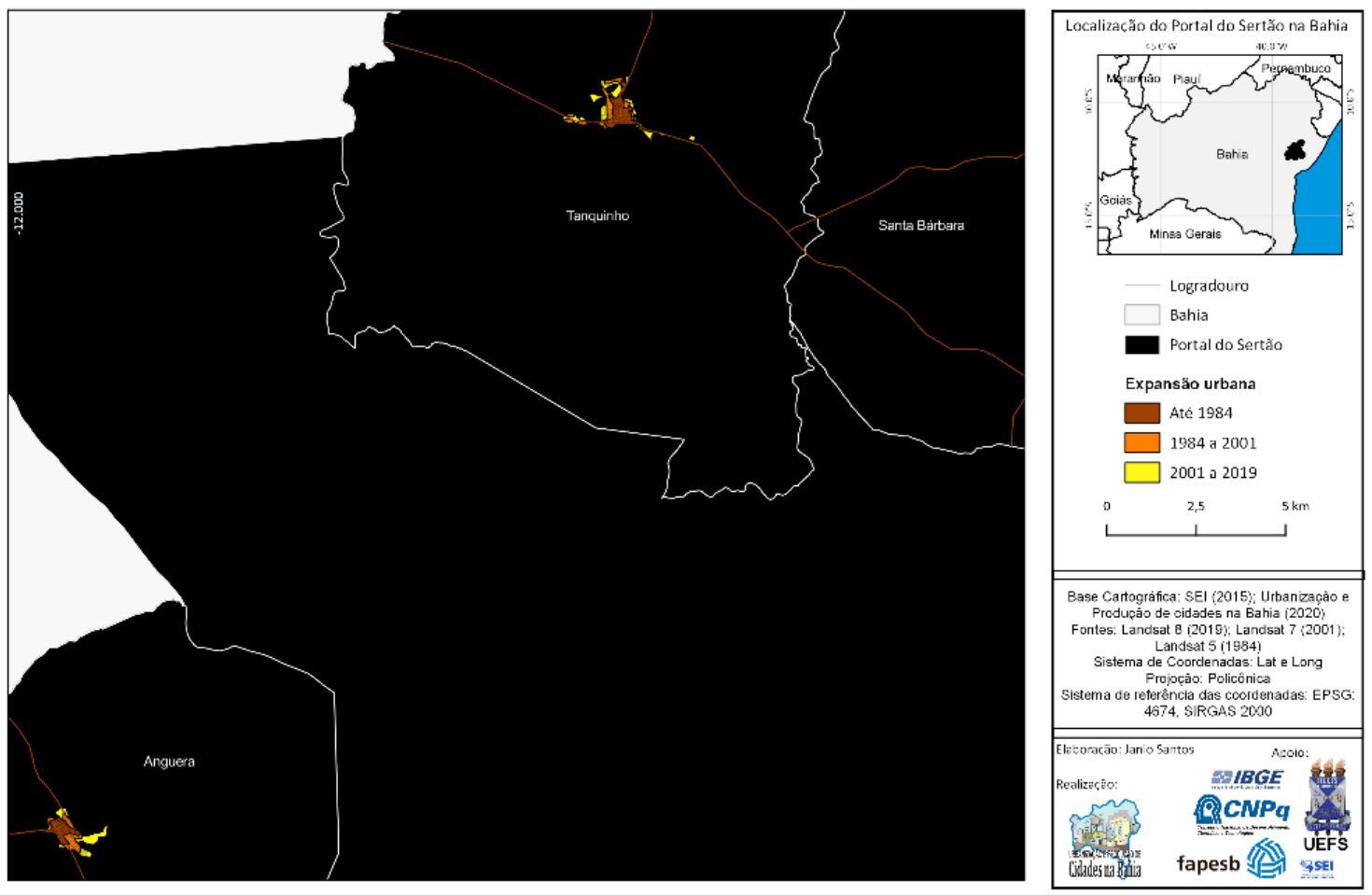

Alguns indicadores permitem avaliar as características da expansão das cidades pequenas do Portal do Sertão. É importante destacar que os dados são dos setores censitários, com base no Censo de 2010 e estão desatualizados. Ademais, algumas cidades possuíam apenas um setor, o que dificulta a distinção de fenômenos e a avaliação mais detalhada da qualidade da expansão urbana.

Foi possível observar três cidades com maior contingente populacional: Santo Estevão, Amélia Rodrigues e Conceição do Jacuípe. Esse panorama tornou explícitas diferenças no interior delas, que apontam uma estruturação com a formação do centro. Amélia Rodrigues tem maior concentração na área norte, enquanto Conceição do Jacuípe no centro-oeste. Conceição da Feira e São Gonçalo dos Campos também se destacaram e seguiram o padrão da formação de uma área central distinta das outras (Mapas 8, 9 e 10).

Cidades menores, como Santanópolis, Anguera e Antônio Cardoso, apresentaram homogeneidade na espacialização da população e não é possível notar contingentes 
demográficos numa mesma área. Portanto, não conformaram claramente o centro e não há distinção sobre onde começa a periferia 
Mapa 8: Total de residentes nas cidades Coração de Maria, Conceição do Jacuípe, Teodoro Sampaio, Terra Nova e Amélia Rodrigues, 2010

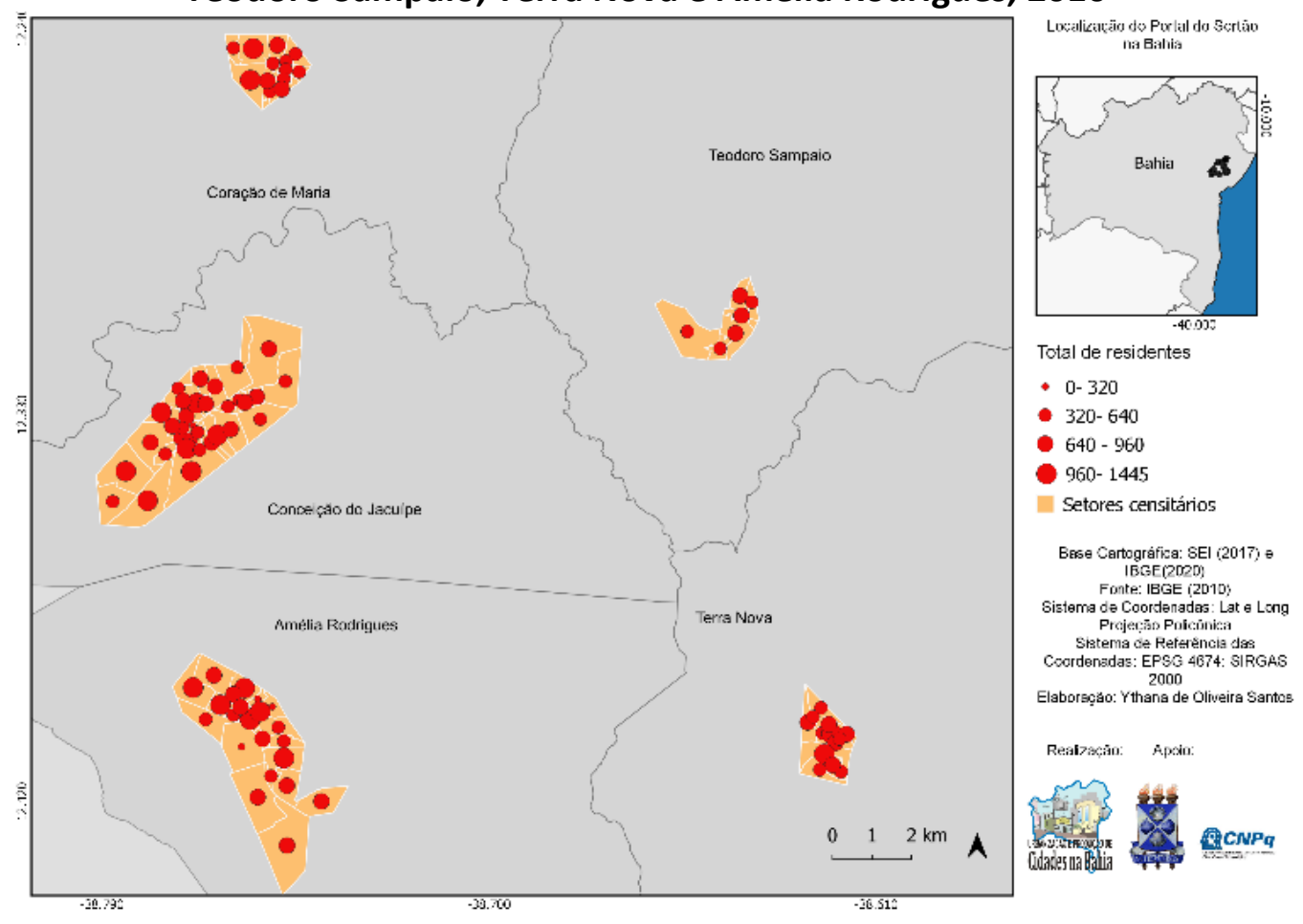

Mapa 9: Total de residentes nas cidades de Anguera, Antônio Cardoso, São Gonçalo dos Campos, Conceição da Feira, Ipacaetá e Santo Estevão, 2010 


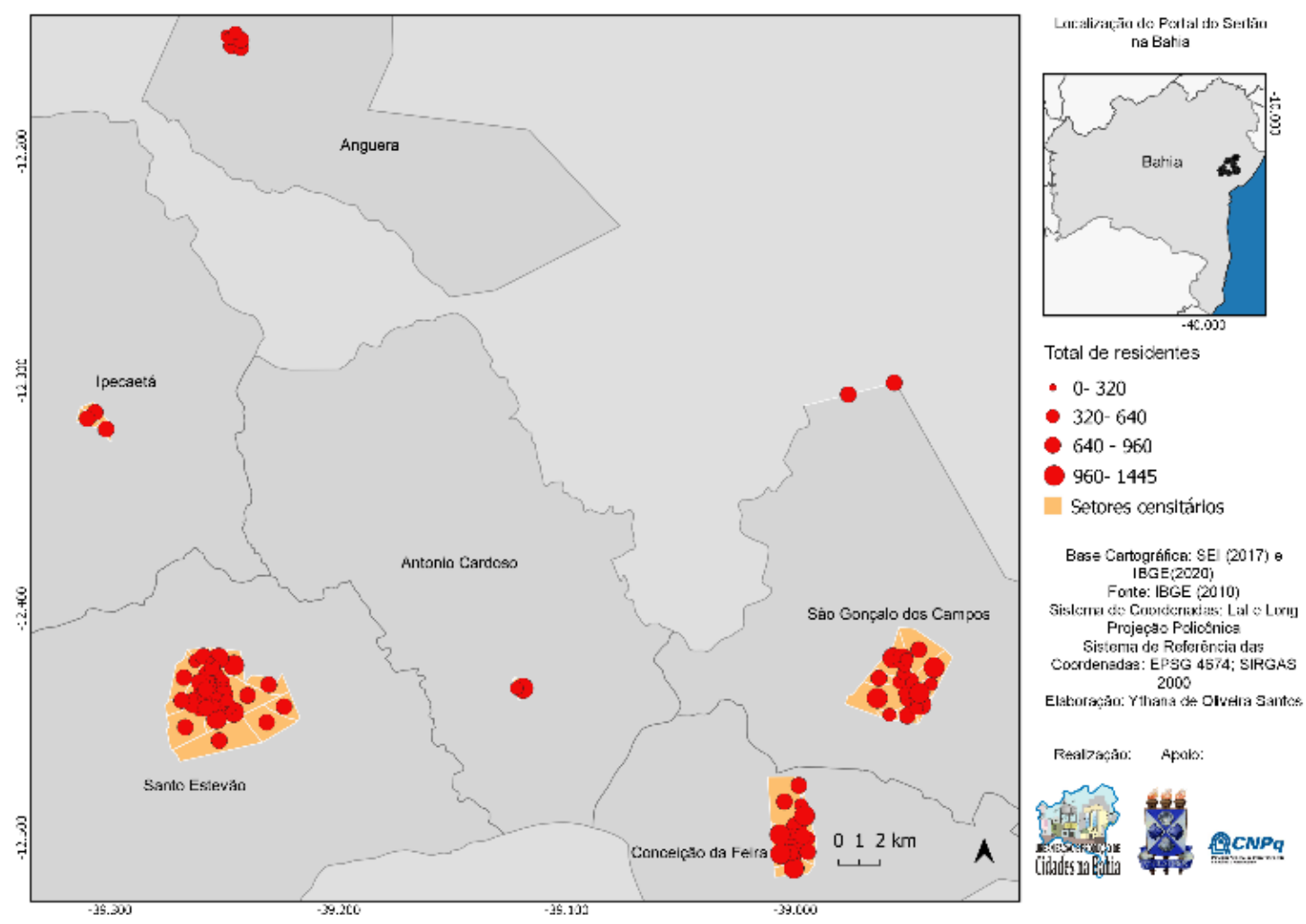

Mapa 10: Total de residentes nas cidades de Tanquinho, Santa Bárbara, Água Fria, Santanópolis e Irará, 2010 


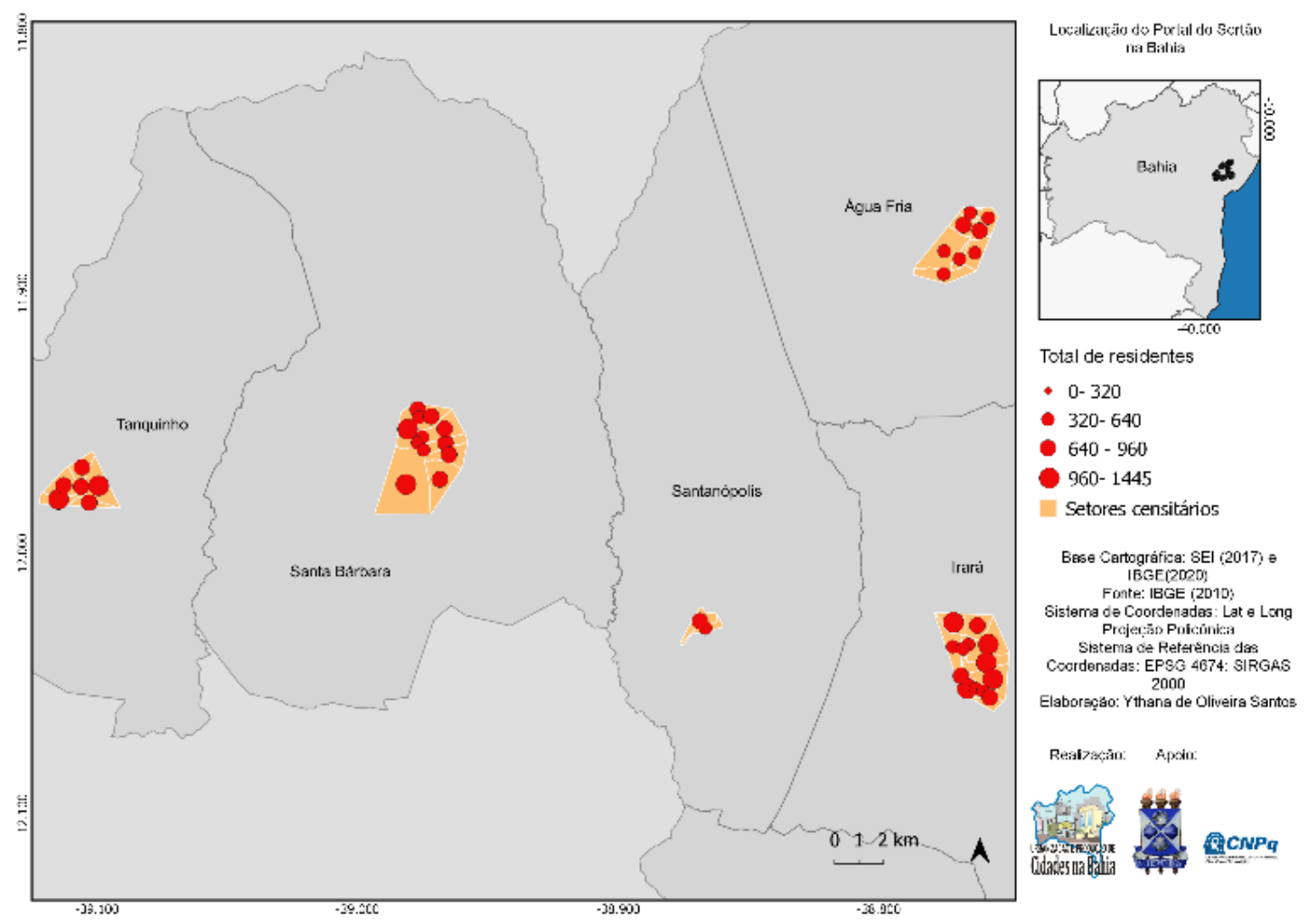

Parte das cidades pequenas do Portal do Sertão possuía menor densidade em áreas mais afastadas do centro e seguia quase que a mesma lógica explicitada pela população total. A tendência de redução das densidades nas "periferias" é ilustrada de modo mais evidente em Conceição do Jacuípe, Amélia Rodrigues, São Gonçalo dos Campos, Santo Estevão e Conceição da Feira (Mapas 11, 12 e 13).

Por outro lado, as cidades menores não seguiram esse padrão. Antônio Cardoso, Santanópolis e Ipecaetá, por exemplo, apresentaram distribuição pouco diferenciada, que se explica pela pequena quantidade de setores censitários e pela baixa extensão territorial. 
Mapa 11: Densidade demográfica das cidades de Coração de Maria, Conceição do Jacuípe, Teodoro Sampaio, Terra Nova e Amélia Rodrigues, 2010

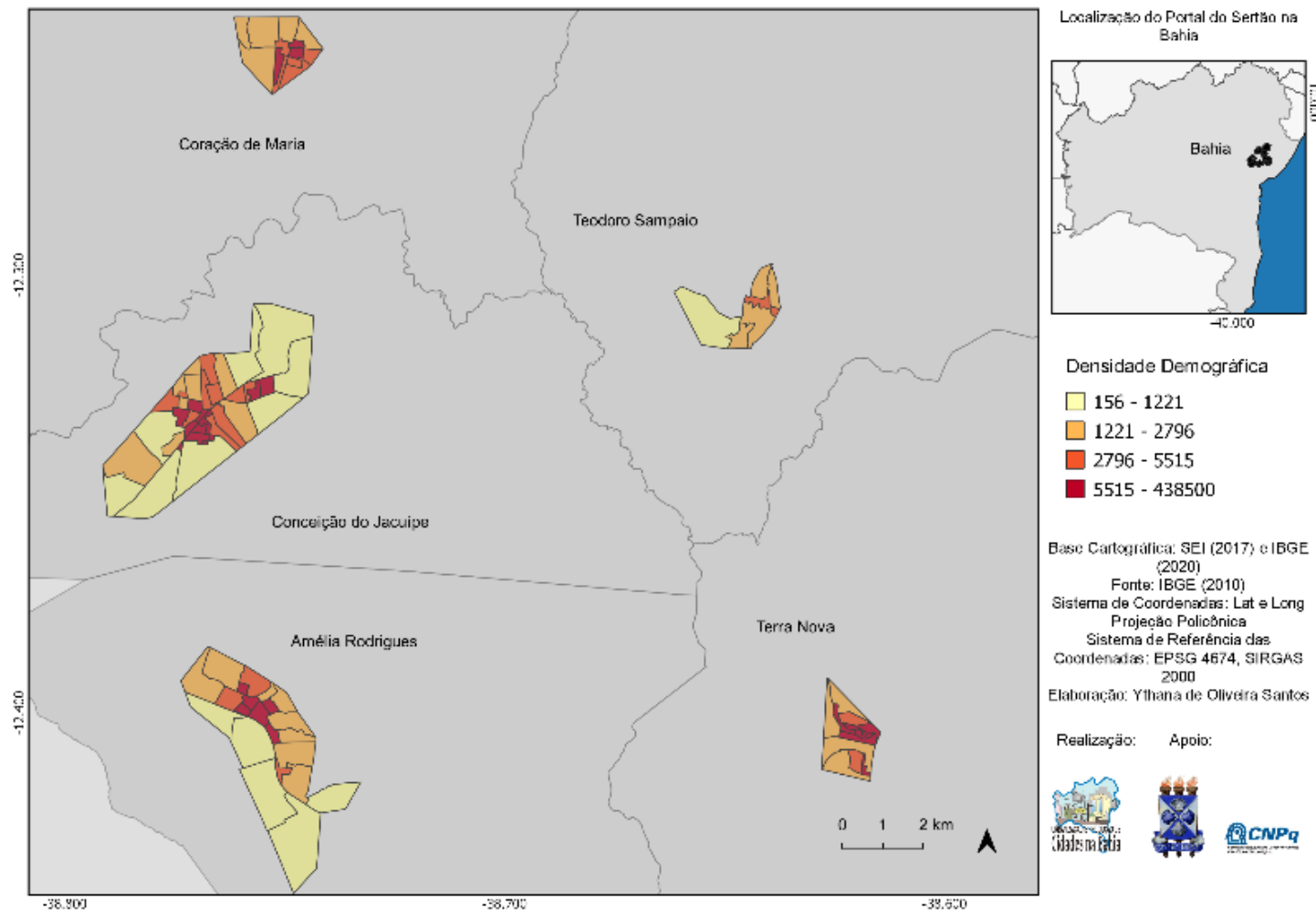

Mapa 12: Densidade demográfica das cidades de Tanquinho, Santa Bárbara, Água Fria, Santanópolis e Irará, 2010 


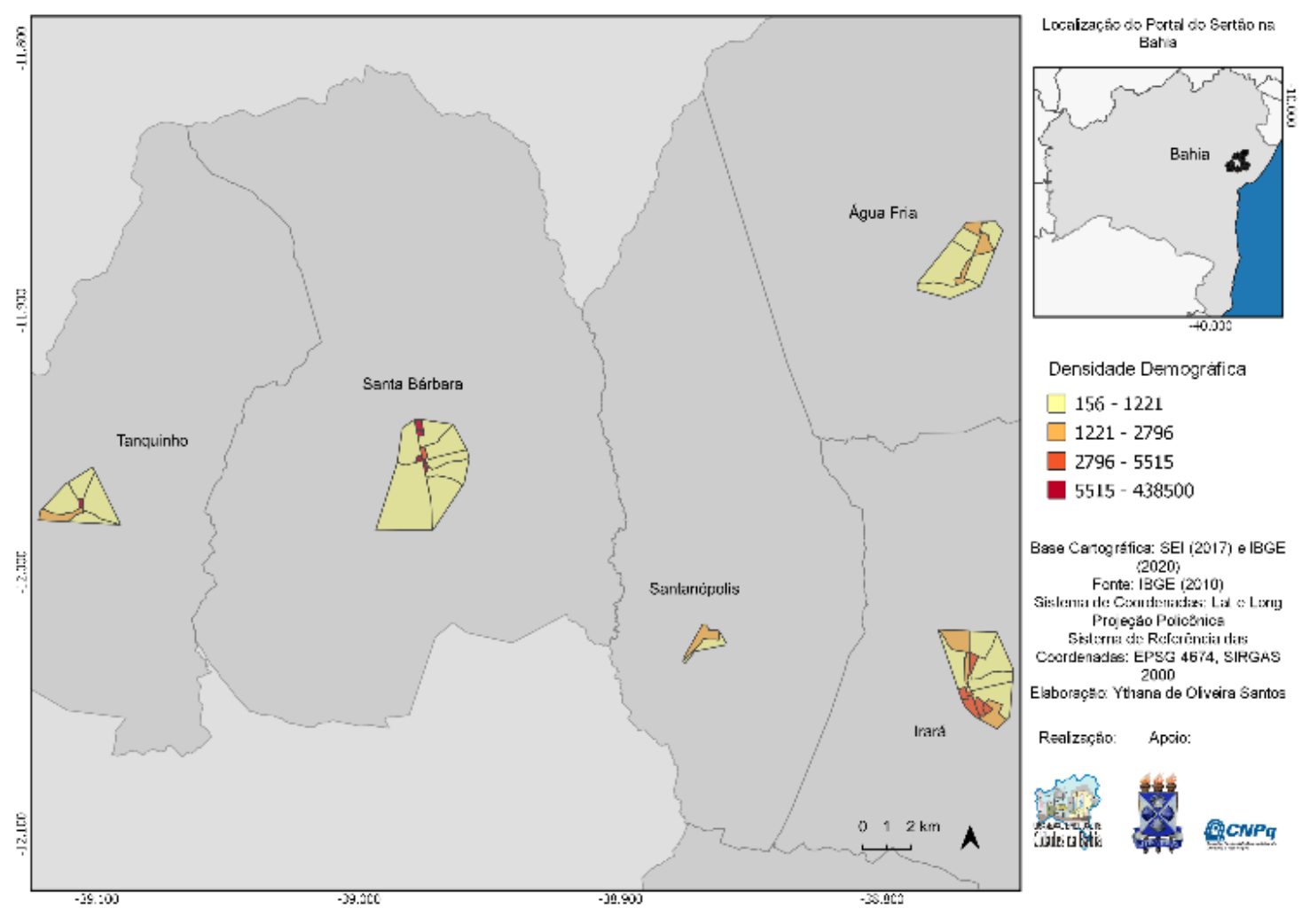

Mapa 13: Densidade demográfica das cidades de Anguera, Antônio Cardoso, São Gonçalo dos Campos, Conceição da Feira, Ipacaetá e Santo Estevão, 2010

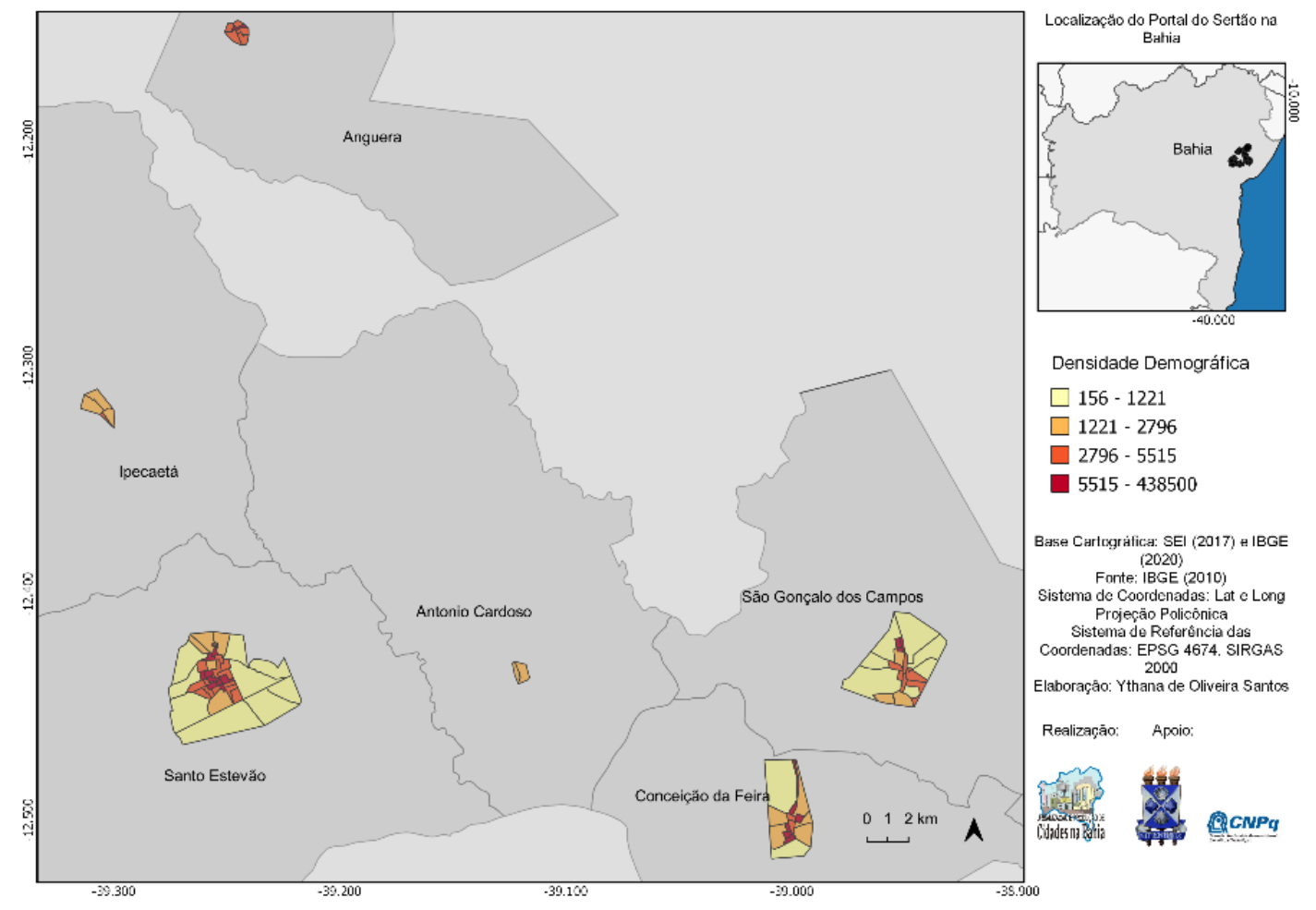

Oliveira Santos; Santos; Borges, Expansão urbana e formação de periferias nas cidades pequenas do Portal do Sertão DOI: https://doi.org/10.51308/continentes.v1i18.300 
Outro fator refere-se à qualidade e ao perfil da moradia. Por meio dos dados, pode-se observar diferenças no padrão das construções empreendidas. Nas cidades de Amélia Rodrigues e Conceição do Jacuípe, 95\% das moradias são inadequadas ou semiinadequadas em quase todos os setores censitários. Essa tendência se repetiu em Conceição da Feira, Santo Estevão e São Gonçalo, todavia, em menor intensidade. O destaque, entretanto, foi notado em Água Fria, que possui o maior percentual de inadequação das moradias e totalizava 95\% em toda a área em 2010 (Mapas 14, 15 e 16).

As desigualdades na expansão das cidades do Portal do Sertão são visíveis e os dados permitem análises acerca do padrão de renda. De maneira geral, os moradores possuíam renda média menor que um salário mínimo, que, em 2010 , equivalia a $\mathrm{R} \$$ 510,00. Entretanto, existem especificidades. Teodoro Sampaio possuía quatro de seus seis setores com renda média até 296,00 reais, isso significa que a maioria da população sobrevivia com $58 \%$ do salário mínimo, à época. As cidades que possuíam um número maior de setores apresentam rendas maiores no centro e menores nas áreas periféricas, a exemplo de Santo Estevão, São Gonçalo e Santa Bárbara (Mapas 17, 18 e 19).

Mapa 14: Taxa de inadequação de moradias nas cidades de Coração de Maria, Conceição do Jacuípe, Teodoro Sampaio, Terra Nova e Amélia Rodrigues, 2010 


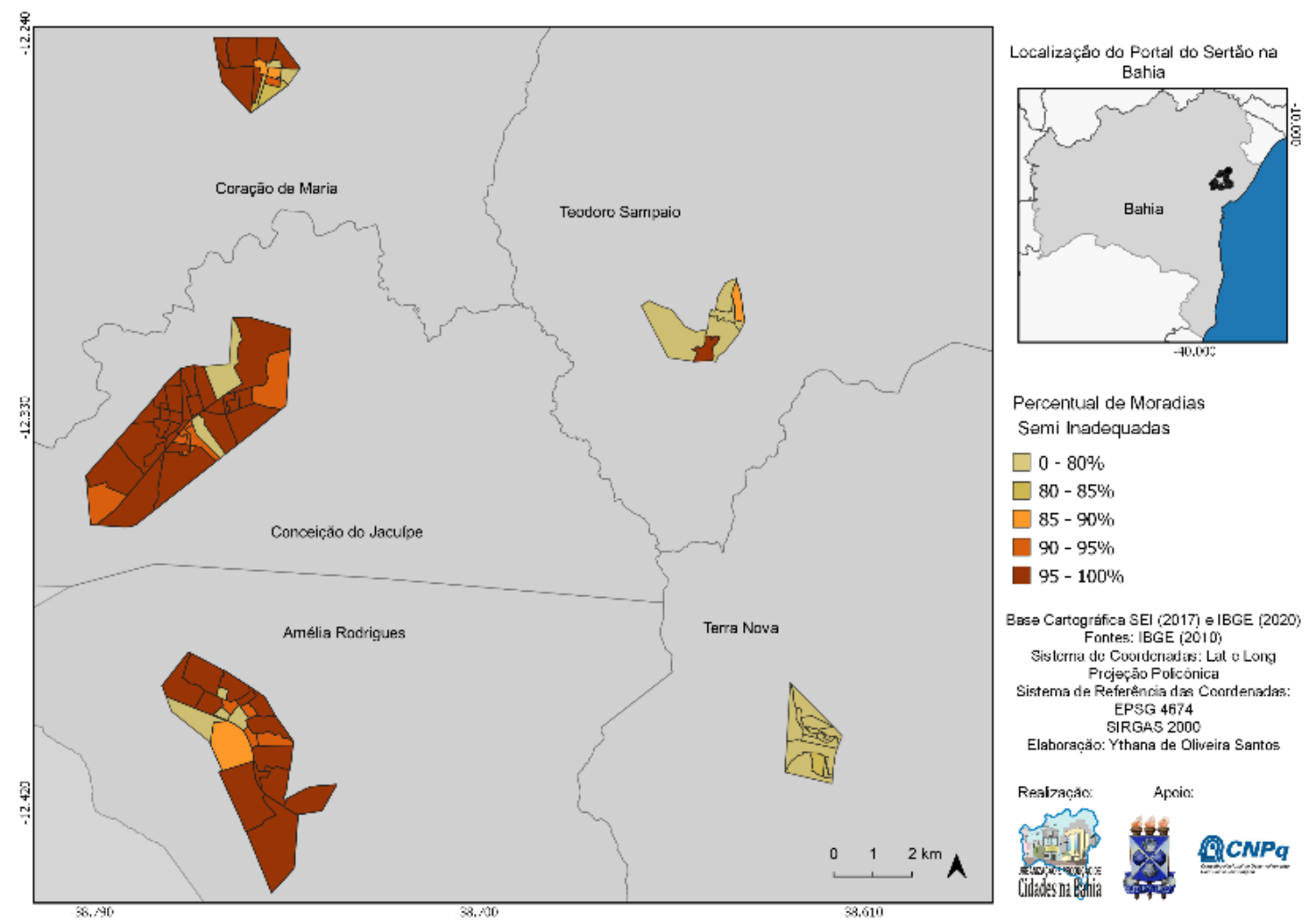


Mapa 15: Taxa de inadequação de moradias nas cidades de Anguera, Antônio Cardoso, São Gonçalo dos Campos, Conceição da Feira, Ipacaetá e Santo Estevão, 2010

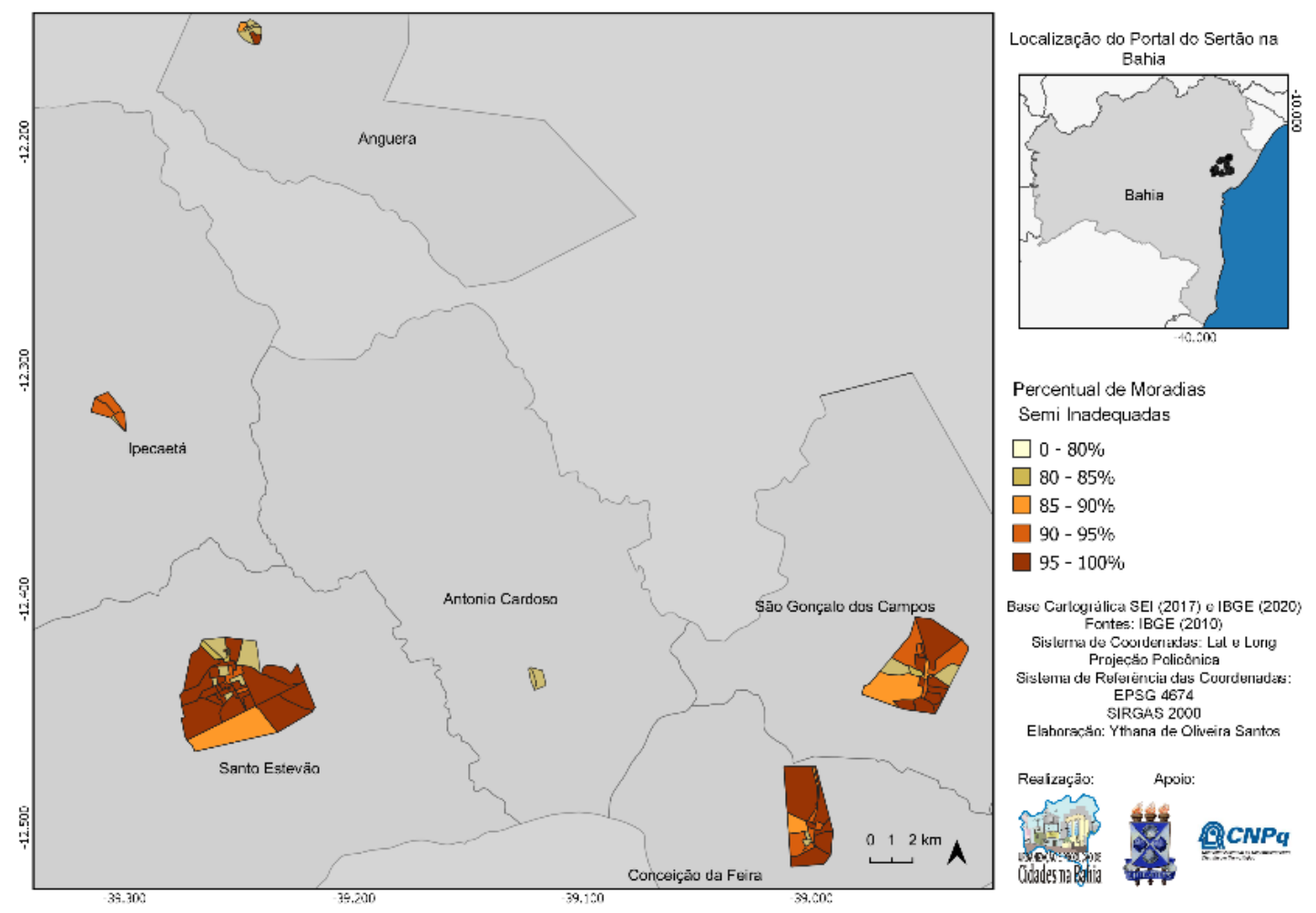

Mapa 16: Taxa de inadequação de moradias nas cidades de Tanquinho, Santa Bárbara, Água Fria, Santanópolis e Irará, 2010 


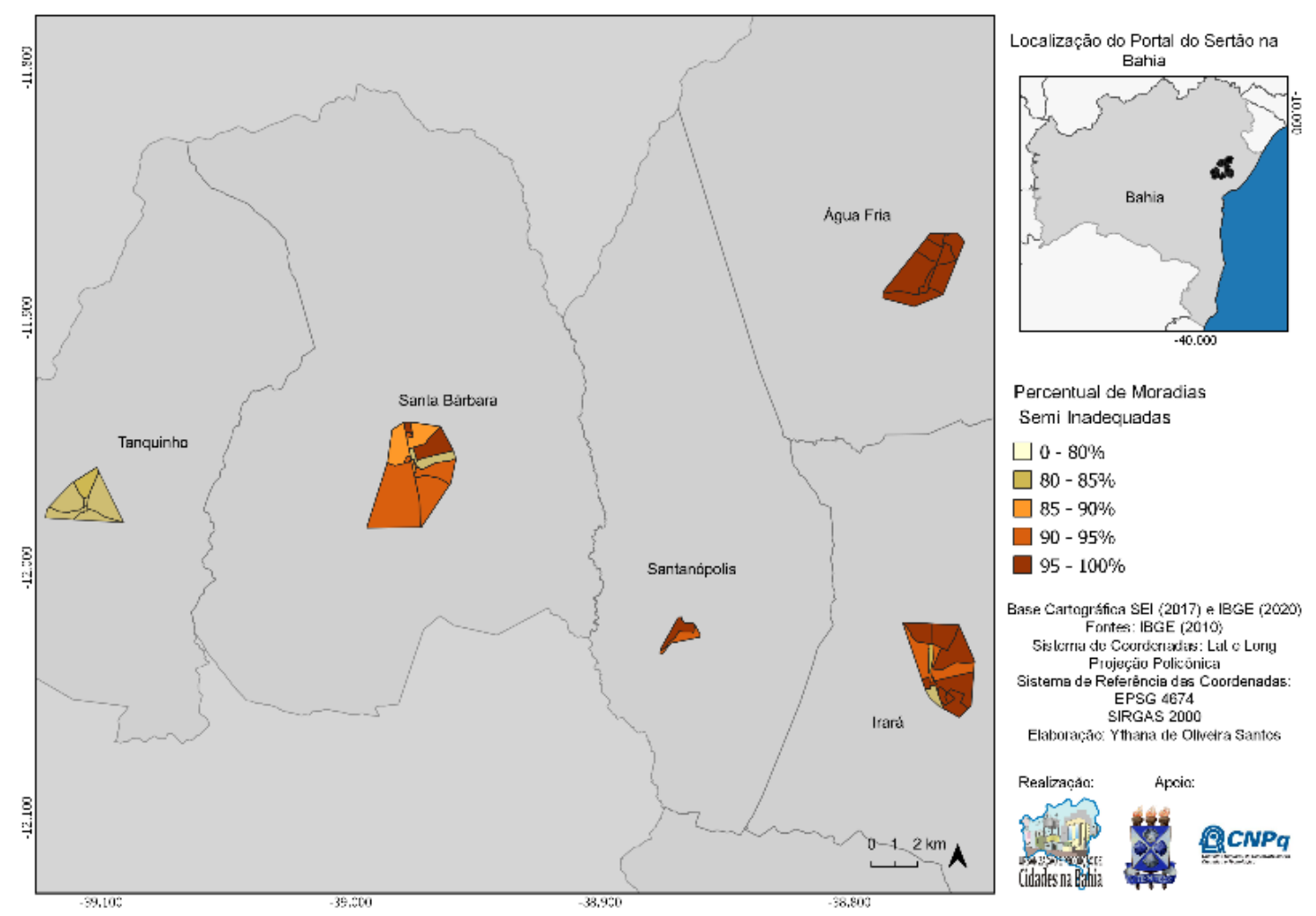

Mapa 17: Renda média da população das cidades de Coração de Maria, Conceição do Jacuípe, Teodoro Sampaio, Terra Nova e Amélia Rodrigues, 2010

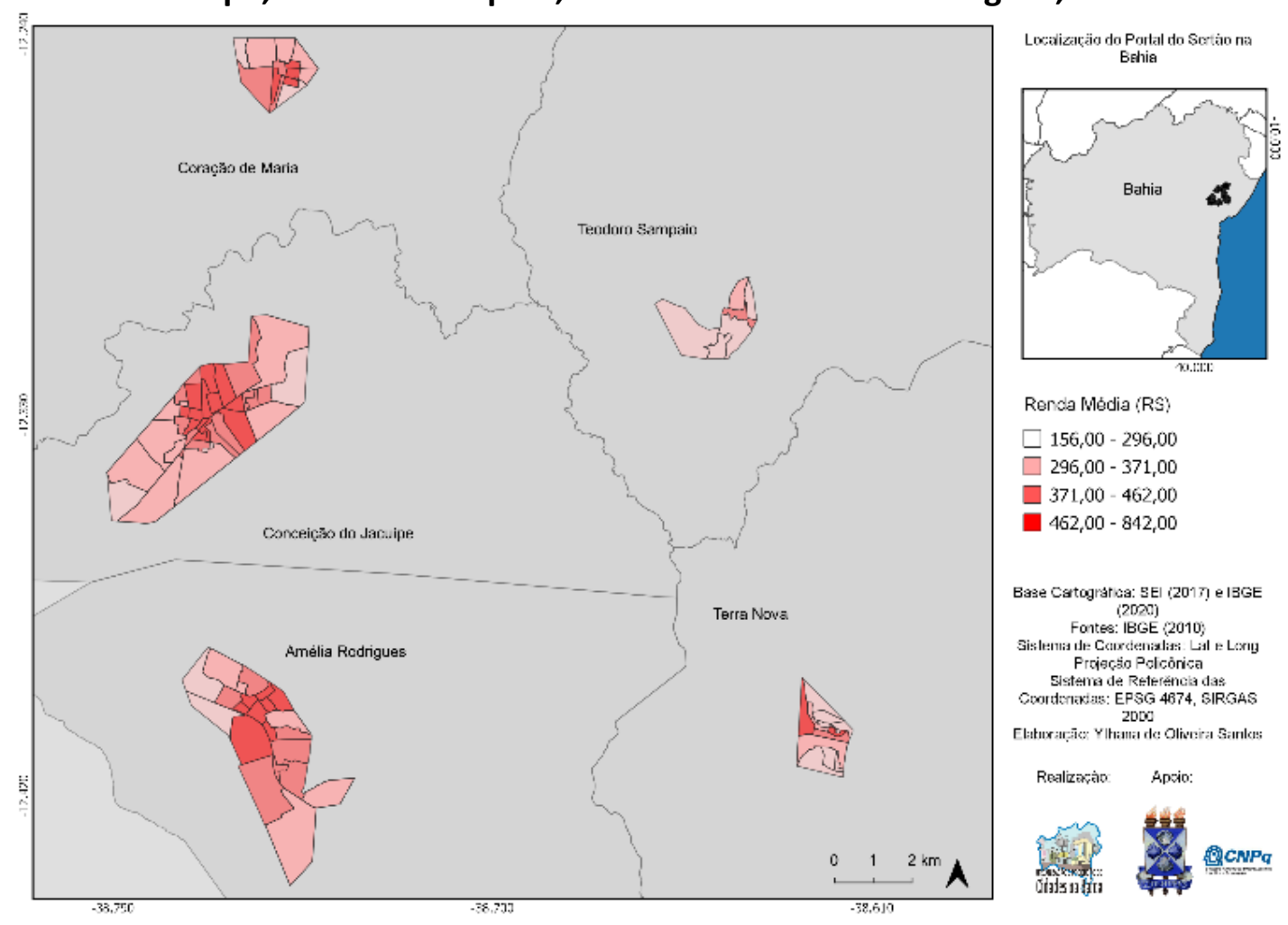

Oliveira Santos; Santos; Borges, Expansão urbana e formação de periferias nas cidades pequenas do Portal do Sertão DOI: https://doi.org/10.51308/continentes.v1i18.300 
Mapa 18: Renda média da população das cidades de Anguera, Antônio Cardoso, São Gonçalo dos Campos, Conceição da Feira, Ipacaetá e Santo Estevão, 2010

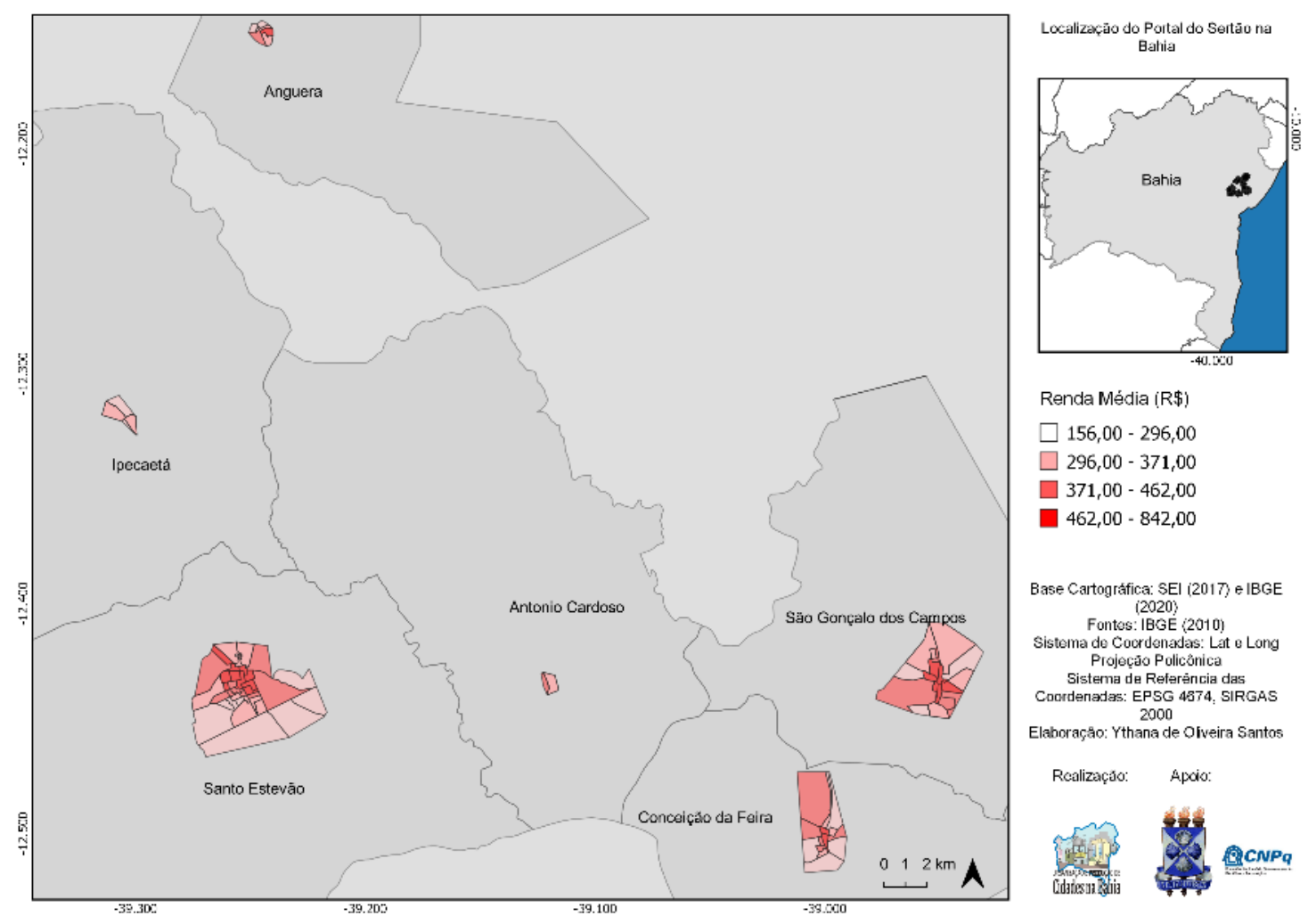

Mapa 19: Renda média da população das cidades de Tanquinho, Santa Bárbara, Água Fria, Santanópolis e Irará, 2010 

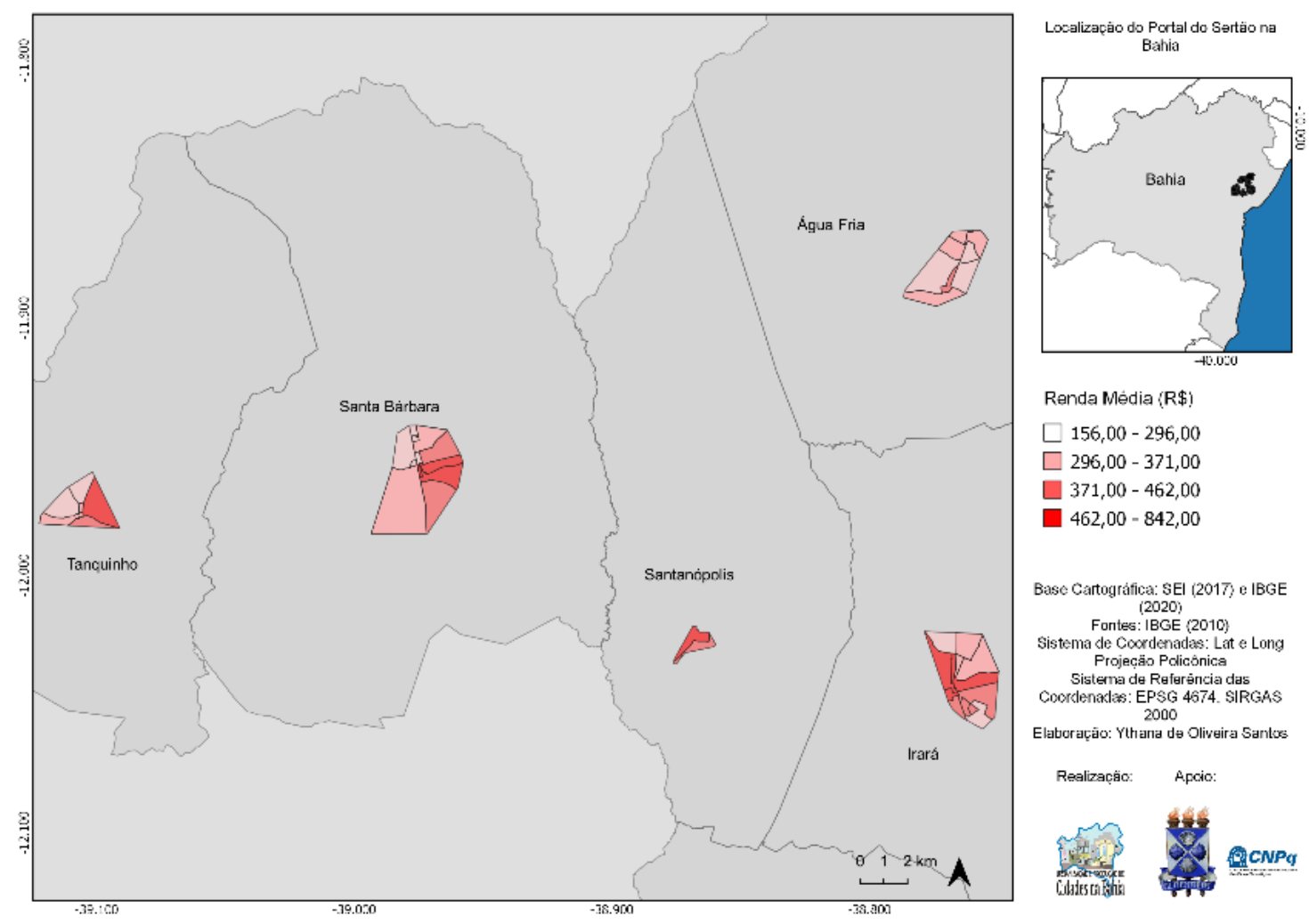

A expansão urbana envolve diversos aspectos e acontece de forma diferente em cada cidade, mesmo nas pequenas. A cidade é o prático sensível que materializa uma lógica hegemônica e relaciona, ao mesmo tempo, global e local. Dessa forma, a expansão modifica-se de acordo com a cidade. Com base em indicadores, foi possível perceber, igualmente, níveis diferentes de qualidade e quantidade que esses processos geram como resultado da lógica urbana atual.

Periferia e centro são pares dialéticos, logo, um não existe sem o outro. Não obstante, surge o primeiro aspecto ao analisar as periferias nas cidades pequenas, já que se pressupõe um centro relativamente definido, algo nem sempre visível. A simples constatação da densidade demográfica não delimita o centro, embora aponte concentração populacional e de serviço mais expressiva.

Nas cidades pequenas, quando as periferias são delineáveis, geralmente se limitam a áreas residenciais, com pouca presença do terciário. Entretanto, diferente do que ocorre em cidades grandes e médias, a população que reside nessas periferias ainda não tem 
tendência a se autossegregar ${ }^{1}$. A valorização fundiária do centro dessas cidades faz com que a parcela mais pobre resida em áreas mais distantes, consequentemente, mais baratas e carentes de serviços.

Há, portanto, tendência à formação de periferias "não planejadas" ou planejadas e sem infraestrutura nas cidades pequenas. Nelas, notam-se baixos índices de qualidade da vida nas áreas em expansão, isso quando o fenômeno acontece. Os agentes imobiliários, estatais e fundiários não se preocupam em adequar esses espaços do ponto de vista urbanístico, pois eles não geram os altos lucros que normalmente encontram-se em maiores áreas urbanas.

Para caracterizar a periferia das cidades pequenas do Portal do Sertão, nos mapas da população total e densidade demográfica, destacam-se Santo Estevão, Amélia Rodrigues e Conceição do Jacuípe. Essas cidades, por serem as maiores dentre as pequenas, possuem densidades, volumes habitacionais e usos do solo diferenciados, o que permite observar um centro e as possíveis áreas de expansão, já com a formação de periferias.

Se analisados os indicadores relacionados à renda média e moradias, verifica-se que as áreas mais afastadas do centro concentram perfis de residentes com níveis baixos de renda e comportam domicílios com níveis altos de inadequação. Outras cidades que apresentam a mesma tendência são: Coração de Maria, Irará e Santa Bárbara.

Sobre a expansão em cidades menores, além da dificuldade na definição concreta de um centro e uma periferia, os setores censitários são, muitas vezes, únicos e não expressam diferenças nos dados demográfico e socioeconômicos.

É possível perceber que as periferias são o produto da expansão urbana e essas se dão de diferentes maneiras e lógicas. Entender a periferia, para além da análise de indicadores demográficos, de renda e inadequação de moradias, perpassa a observação da escala de cidade, que constitui a materialidade do fenômeno, conforme aponta SPOSITO (2004). Por um lado, ela sempre expressa a lógica hegemônica e desigual do

\footnotetext{
${ }^{1}$ Relativa a decisão e capacidade que as camadas de médias e altas rendas possuem em viver em áreas reclusas, fora dos centros, geralmente, em condomínios fechados.
} 
sistema capitalista. Contudo, apresenta particularidades e os papeis que the são atribuídos modificam-se no tempo.

\section{"Para compreender as periferias que se formam nas cidades pequenas não basta analisar apenas os graus de expansão, mas igualmente indicadores sobre a qualidade e a quantidade desse processo. Os principais afetados pela expansão urbana são os residentes dessas cidades, mais ainda, os da periferia, pois são eles que vivem a falta de saneamento básico, infraestrutura, mobilidade urbana e moradias adequadas".}

Cada cidade tende a expandir e, consequentemente, produz periferias diferentes, ainda que produto de ordens gerais. As modificações quase nunca acontecem de maneira "natural", pois existem interesses que as regem. Isso ocorre com a expansão urbana, que em algumas cidades pequenas passaram a representar facetas de segregação ${ }^{2}$ e profundas transformações no espaço urbano.

A fragmentação ${ }^{3}$ existente nas grandes e médias cidades é

impulsionada por agentes do capital que convertem o solo rural em urbano, produzem condomínios fechados e causam valorização nas áreas periféricas. Todavia, isso não está presente na maioria das cidades pequenas do Portal do Sertão. Em primeiro lugar, porque nessas, algumas vezes, não se consegue distinguir o centro e a periferia, já que a expansão é assaz incipiente; em segundo, porque o principal produto da expansão na cidade pequena ainda é a periferia pobre, pois as pessoas com rendas maiores se concentram no centro.

Ainda assim, há que ressaltar a oferta de novos produtos imobiliários em três dessas cidades, algo relacionado à expansão urbana, a dinâmica econômica e a ampliação do mercado imobiliário para além dos limites de Feira de Santana. Por isso, verificam-se

\footnotetext{
${ }^{2}$ Processos espaciais que impelem a população pobre a residir em áreas sem infraestrutura, carentes serviços básicos. Referem-se especificamente ao aspecto residencial e, em geral, têm relação com questões sociais, étnicas e/ou raciais.

${ }^{3}$ Lógicas espaciais que incorrem na ruptura da convivência entre grupos diferentes na cidade e, em geral, têm relação com questões de renda. Os condomínios fechados, shopping centers, áreas de status ou "gourmetizadas" são as bases frequentes do fenômeno.
} 
condomínios fechados em áreas periféricas de Conceição do Jacuípe, como Horto Residencial e Orto Tropical; São Gonçalo dos Campos, com o Sítios Campo Belo e o Fazenda Pedra do Lago; e Amélia Rodrigues, com o Residencial Recanto da Volta. E ainda que sejam assaz recentes, revelam a imposição de padrões de consumo nas cidades pequenas e que suas periferias também estão sendo modificadas.

Por um lado, as periferias pressupõem, de forma geral, uma lógica geométrica. Sendo assim, são áreas relativamente afastadas do centro, todavia que podem ou não ser mais valorizadas e que podem ou não ter serviços e infraestrutura, a depender do tamanho e da escala da cidade. O Estado é o principal ente na regulamentação dessas periferias, entretanto, age em favor dos agentes fundiários e imobiliários, como em outras cidades maiores.

Na maioria das cidades pequenas, não há expressivas faixas da classe média a morar fora do centro, nem desvalorização dessa área, que ainda é o maior foco do interesse dos agentes imobiliários, quando produzem habitação para as camadas maiores de rendas. As áreas centrais e pericentrais continuam a ser ocupadas pelas residências das classes de maior renda nessas cidades e as pessoas com menor poder aquisitivo são expurgadas para as periferias.

Para compreender as periferias que se formam nas cidades pequenas não basta analisar apenas os graus de expansão, mas igualmente indicadores sobre a qualidade e a quantidade desse processo. Os principais afetados pela expansão urbana são os residentes dessas cidades, mais ainda, os da periferia, pois são eles que vivem a falta de saneamento básico, infraestrutura, mobilidade urbana e moradias adequadas. Como assinalam MARICATO (2002) e CARLOS (2007), compreender as formas desiguais e segregacionistas da expansão urbana capitalista é fundamental para pensar o caminho para formação de uma sociedade democrática e justa, independente do porte da cidade.

\section{Considerações finais}

O estudo das cidades pequenas do Portal do Sertão demonstra que o processo de expansão ocorre, todavia, com intensidades, lógicas e efeitos distintos. Em algumas 
delas, como Conceição do Jacuípe e Santo Estevão, tornou-se visível a divisão territorial das atividades no espaço intraurbano, com delineamento de um centro e uma periferia; em outras, tal distinção é difusa ou mesmo não existe, algo perceptível em Antônio Cardoso e Ipacaetá. Isso revela que as relações que produzem o espaço das pequenas cidades são complexas e resultam em estruturas urbanas heterogêneas e desiguais. A expansão urbana, embora também esteja relacionada com a migração campesina para as cidades, é uma dinâmica que inclui o uso do solo e os interesses imobiliários e especulativos. Ela fragmenta a cidade em áreas residenciais e comerciais, além de segregar seus residentes, geralmente, por classes de renda, o que forma centros e periferias e afeta a população e o direito à cidade.

Um produto da expansão urbana são as periferias, definidas geometricamente pela distância em relação ao centro e pelos conteúdos nelas existentes. Entretanto, nas cidades pequenas, expressam tendência à concentração de pobres, isso quando conseguem ser distinguidas. Um problema comum em análises de tais cidades consiste justamente na distinção de centros e periferias, pois algumas apresentam baixa extensão territorial e poucos setores censitários, o que dificulta ou limitam certas investigações. Logo, em algumas cidades pequenas é possível distinguir as periferias. Contudo, em outras não.

Nas cidades onde foi possível distinguir, nota-se tendência à concentração populacional no centro, enquanto na periferia a densidade é menor. Esse fato foi observado em Conceição do Jacuípe, São Gonçalo dos Campos, Amélia Rodrigues e Santo Estevão, que possuem maior dinâmica econômica, diferenças na estruturação do espaço intraurbano e nos padrões de renda e moradia, o que conforma áreas centrais de residência das camadas de maiores rendas e periferias mais pobres. Afirma-se isso, ainda que mudanças importantes estejam a ocorrer, face à implantação de condomínios em algumas.

A junção entre estudos que analisam indicadores qualitativos e quantitativos da expansão em pequenas cidades e as práticas espaciais dos moradores deve ser destacado, pois um fator complementa o outro e elucida questões importantes, já que 
cada periferia, assim como sua cidade, é única, mesmo resultante de processes que são gerais.

\section{Referências bibliográficas}

CHAVEIRO, E. F.; ANJOS, A. F. A periferia urbana em questão: um estudo socioespacial de sua formação. Boletim goiano de Geografia, Goiânia, v.27, n.25, jan-jun 2007, p. 181-197.

CARLOS, A. F. A. O espaço urbano: novos escritos sobre a cidade. São Paulo: Labur Edições, 2007

CORRÊA, R. L. As pequenas cidades na confluência do urbano e do rural. Geousp, Espaço e Tempo, n. 30, p. 5-12, 2011. , O espaço urbano. São Paulo: Ática S.A, 1989, p. 7-10.

IBGE. Censo Demográfico, 2000. Sidra: Banco de dados. Disponível em: http://www.sidra.ibge.gov.br, acesso em: 27 jul 2019.

- Censo Demográfico, 2010. Sidra: Banco de dados. Disponível em: http://www.sidra.ibge.gov.br, acesso em: 27 jul 2019.

Dados sobre Produto Interno Bruto 1999 e 2009. Sidra: Banco de dados. Disponível em: http://www.sidra.ibge.gov.br, acesso em: 27 jul 2019.

INPE. Catálogo de Imagens. Disponível em: http://www.dgi.inpe.br/CDSR, acesso em: 27 jul 2019.

MAIA, D. S. Cidades pequenas: como defini-las? Apontamentos para os estudos sobre as cidades pequenas. In: OLIVEIRA, J. A. (Org.). Cidades brasileiras: territorialidades, sustentabilidade e demandas sociais. Manaus: Editora da UFAM, 2009. v. 1.

MARICATO, E. As ideias fora do lugar e o lugar fora das ideais. In: ARANTES, Ó; VAINER, C; MARICATO, E (Org.) A Cidade do pensamento único: desmanchando consensos. 3ạ ed. Petrópolis: Vozes, 2002, p. 121-192.

MOURA, G. G.; SOARES, B. R. A periferia de Uberlândia/MG: da sua origem até a sua expansão nos anos 1980. Caminhos de Geografia. Uberlândia, v.10, n.32, p. 22-40, dez/2009. 
SANTOS, J. Contribuição teórico-metodológica ao estudo das pequenas cidades, com base em pesquisas sobre a Bahia. In: BRANDÃO, P. R. B. (Org.). Cidades médias e pequenas: reflexões sobre dinâmicas espaciais contemporâneas. Curitiba: Appris, 2019, p. 52-84.

Urbanização e produção de cidades no/do território de identidade Portal do Sertão. Geografia Ensino e Pesquisa, Santa Maria, v. 24, ed 6, p.1-39, 28 fev. 2020.

SANTOS, M. Da totalidade ao lugar. São Paulo: Edusp, 2005

SILVA, J. M. Valorização fundiária e expansão urbana recente de Guarapuava-PR. 1995. 181f. Dissertação (Mestrado em Geografia). Instituto de Geociências. Universidade Federal de Santa Catarina. Florianópolis, 1995.

SINGER, P. O uso do solo urbano na economia capitalista. In: MARICATO, E. (Org.) A produção capitalista da casa (e da cidade) no Brasil industrial. 2a ed. São Paulo: Editora Alfa e Omega, 1982, v.1, p. 21-36.

SPOSITO, M. E. B. O chão em pedaços: urbanização, economia e cidades no estado de São Paulo. 2004. 504F Tese (Livre Docência)-Faculdade de Ciências e Tecnologia, Universidade Estadual Paulista, Presidente Prudente

Data de Submissão: 26/09/2020

Data do Aceite: 08/03/2021 